\title{
Pseudomonas aeruginosa Exopolyphosphatase Is Also a Polyphosphate: ADP Phosphotransferase
}

\author{
Paola R. Beassoni, Lucas A. Gallarato, Cristhian Boetsch, \\ Mónica N. Garrido, and Angela T. Lisa \\ Departamento de Biología Molecular, FCEFQyN, Universidad Nacional de Río Cuarto, Ruta 36 Km 601, Río Cuarto, \\ 5800 Córdoba, Argentina
}

Correspondence should be addressed to Paola R. Beassoni; paobeassoni@gmail.com

Received 30 July 2015; Accepted 27 September 2015

Academic Editor: Sunney I. Chan

Copyright ( $) 2015$ Paola R. Beassoni et al. This is an open access article distributed under the Creative Commons Attribution License, which permits unrestricted use, distribution, and reproduction in any medium, provided the original work is properly cited.

Pseudomonas aeruginosa exopolyphosphatase ( $p a \mathrm{Ppx}$; EC 3.6.1.11) catalyzes the hydrolysis of polyphosphates (polyP), producing poly $\mathrm{P}_{n-1}$ plus inorganic phosphate $\left(\mathrm{P}_{\mathrm{i}}\right)$. In a recent work we have shown that paPpx is involved in the pathogenesis of $P$. aeruginosa. The present study was aimed at performing the biochemical characterization of this enzyme. We found some properties that were already described for E. coli $\mathrm{Ppx}(e c \mathrm{Ppx})$ but we also discovered new and original characteristics of paPpx: (i) the peptide that connects subdomains II and III is essential for enzyme activity; (ii) $\mathrm{NH}_{4}{ }^{+}$is an activator of the enzyme and may function at concentrations lower than those of $\mathrm{K}^{+}$; (iii) $\mathrm{Zn}^{2+}$ is also an activator of $p a \mathrm{Ppx}$ and may substitute $\mathrm{Mg}^{2+}$ in the catalytic site; and (iv) paPpx also has phosphotransferase activity, dependent on $\mathrm{Mg}^{2+}$ and capable of producing ATP regardless of the presence or absence of $\mathrm{K}^{+}$or $\mathrm{NH}_{4}{ }^{+}$ions. In addition, we detected that the active site responsible for the phosphatase activity is also responsible for the phosphotransferase activity. Through the combination of molecular modeling and docking techniques, we propose a model of the $p a P p x \mathrm{~N}$-terminal domain in complex with a polyP chain of 7 residues long and a molecule of ADP to explain the phosphotransferase activity.

\section{Introduction}

polyP are linear polymers containing few to several hundred residues of orthophosphate linked by energy-rich phosphoanhydride bonds. The presence of this polymer has been detected in all kinds of living organisms, including higher organisms. Main enzymes involved in the synthesis of polyP are the polyphosphate kinases (Ppks; EC 2.7.4.1), which catalyze the formation of polyP from ATP (Ppk1) and GTP (Ppk2). Endo- and exopolyphosphatases are the most important enzymes involved in the utilization of polyP. In bacteria only exopolyphosphatases have been described [1].

The implication of Ppk and polyP in the virulence of $P$. aeruginosa has been clearly demonstrated, since a $p p k 1$ knockout mutant was defective not only in various forms of motility [2,3] but also in biofilm development, quorumsensing, synthesis of virulence factors such as elastase and rhamnolipid, virulence of the burned-mouse pathogenesis model [4], and general stress and stringent responses [5]. However, little is known about the relation between Ppx and its possible role in the pathogenesis of this bacterium $[3,6,7]$. We have recently confirmed that $\mathrm{Ppx}$ is relevant for pathogenesis in P. aeruginosa [8], due to the fact that the $p p x$ null mutant was defective in the production of factors associated to both acute infection (e.g., motilitypromoting factors, blue/green pigments production, and quorum-sensing C6-C12 homoserine lactones) and chronic infection (e.g., rhamnolipids and biofilm formation). Thus, there is enough evidence that both Ppk and Ppx as well as polyP balance contribute to the pathogenesis of $P$. aeruginosa.

Concentrations of polyP in $P$. aeruginosa are severalfold greater than in E. coli $[9,10]$. P. aeruginosa $\mathrm{Ppx}$ ( $p a \mathrm{Ppx})$ activity was described for the first time by Miyake and collaborators [11], and its gene was later cloned and expressed in E. coli [12]. The crystal structure and analysis of E. coli $\mathrm{Ppx}(e c \mathrm{Ppx})$ have been reported $[13,14]$ and the active site of 
the enzyme was suggested as a cleft where the polyP chain would bind. Several authors have determined that subdomains I and II of the $\mathrm{N}$-terminal region of ecPpx represent the catalytic portion, whereas the C-terminal region, formed by subdomains III and IV, was proposed to be involved in substrate binding [13-15].

The role of polyP as phosphate donor in phosphoryl transfer reactions has also been described [16]. Polyphosphate AMP phosphotransferase transfers a $\mathrm{P}_{\mathrm{i}}$ from polyP to AMP producing ADP; afterwards, ATP is regenerated by the sequential action of the adenylate kinase. In addition, the glucose phosphotransferase catalyzes the phosphoryl transfer from polyP to glucose or glucosamine producing glucose 6-phosphate and glucosamine 6-phosphate, respectively. Finally, it is well known that Ppk is capable of catalyzing the inverse reaction to produce ATP from ADP + polyP (known as polyP:ADP phosphotransferase activity) (see [16] and references cited therein). To our knowledge, a similar activity of Ppx in prokaryotes has never been reported. Considering that other enzymes of the same family, such as the Ppx/GPPA of Aquifex aeolicus (aaPpx; EC 3.6.1.40), act on a nucleotide (pppGpp) [17], we hypothesized that in the active site of $p a \mathrm{Ppx}$ there could be enough space to bind a nucleotide molecule such as $\mathrm{ADP}$ and that the reaction of ATP production using polyP as $\mathrm{P}_{\mathrm{i}}$ donor could be possible. In the present work, we present results of the cloning and purification of $p a \mathrm{Ppx}$, in full-length, N-terminal, and Cterminal domains variants and we describe the preference of the full-length enzyme for long polyP chains, pointing the $\mathrm{C}$ terminal domain as responsible for this behavior. We show that $p a \mathrm{Ppx}$ is also a polyphosphate:ADP phosphotransferase and that the active site is the same as that one involved in the hydrolase activity. Finally, we present a structural model of full-length $p a \mathrm{Ppx}$, in closed conformation, based on the atomic coordinates of ecPpx [13] and a model of the N-terminal domain of $p a \mathrm{Ppx}$ in an open state based on atomic coordinates of $a a \mathrm{Ppx}$ [17]. We also propose a model of the paPpx N-terminal domain in complex with a polyP chain of 7 residues long and a molecule of ADP to explain the phosphotransferase activity through docking techniques.

\section{Materials and Methods}

2.1. Materials. Oligonucleotide primers were purchased from Integrated DNA Technologies (IDT, USA). ADP and sodium phosphate glass type $25,45,65$, and 75 (poly $_{25}$, poly $_{45}$, poly $\mathrm{P}_{65}$, and poly $\mathrm{P}_{75}$ ) residues were purchased from Sigma (St. Louis, MO). The rest of the chemicals used were of proanalysis quality.

\subsection{Bacterial Strains and Growth Conditions. P. aeruginosa} PAO1 and E. coli strains were grown in LB medium at $37^{\circ} \mathrm{C}$. For recombinant $E$. coli the $\mathrm{LB}$ medium contained $150 \mu \mathrm{g} \mathrm{mL}^{-1}$ ampicillin. E. coli XL10-Gold strain (Stratagene) was used for plasmid maintenance while E. coli BL21CodonPlus strain (Stratagene) was used for protein expression.
2.3. DNA Methodology. DNA isolation, both genomic and plasmidic, was performed using commercial kits (Promega or Qiagen, resp.). Restriction enzymes and T4 ligase were used according to the manufacturer's instructions (Promega). DNA fragments were purified from agarose gels employing a QIAquick kit (Qiagen). To avoid introducing errors due to PCR or subcloning procedures, all resultant plasmids were partially sequenced by Macrogen, Inc. (Gangseo-gu, Seoul, South Korea).

2.4. Expression and Purification of paPpx Variants. The methods used were based on N-terminal fusion His-tagged proteins. The $1.5 \mathrm{~Kb}, 0.94 \mathrm{~Kb}, 0.91 \mathrm{~Kb}$, and $0.56 \mathrm{~Kb}$ fragments encoding the $506\left(p \mathrm{Ppx}_{(1-506)}\right), 314\left(\mathrm{~N}-p a \mathrm{Ppx}_{(1-314)}\right), 303$ $\left(\mathrm{N}-p a \mathrm{Ppx}_{(1-303)}\right)$, and $192\left(\mathrm{C}-p a \mathrm{Ppx}_{(315-506)}\right)$ amino acids of Ppx were amplified from $P$. aeruginosa PAO1 wild-type chromosomal DNA through PCR with the oligonucleotides listed in Table 1. PCR-amplified DNA fragments were cloned into the pCR2.1-TOPO vector to generate pCR-ppx, pCR$\mathrm{N} p p x$, pCR-N303ppx, and pCR-Cppx, respectively. These plasmids were later transformed into E. coli XL10-Gold, followed by selection of ampicillin-resistant transformants. For gene expression, the different amplified $p p x$ fragments were restricted by EcoRI-NdeI enzymes and subcloned into pET-15b (Novagen) as N-terminal fusions to a 6xHis-tag, generating $\mathrm{pET}-p p x$, pET-Nppx, pET-N303ppx, and pETC $p p x$, respectively. These plasmids were then transformed into E. coli BL21-CodonPlus. The resulting transformants were grown and induced as previously described by [18]. Affinity purification on $\mathrm{Ni}$-agarose columns was used to perform protein purification, following the manufacturer's protocol (the QIA expressionist, Qiagen). Pure recombinant proteins were dialyzed against $10 \mathrm{mM}$ Tris- $\mathrm{HCl}, \mathrm{pH} 8.0$, $150 \mathrm{mM} \mathrm{NaCl}, 150 \mathrm{mM}$ imidazole, and 30\% glycerol. Consecutive dialysis steps were performed to reduce the imidazole concentration to approximately $10 \mathrm{mM}$. The $6 x$ His-tag was subsequently removed using a thrombin cleavage capture kit (Novagen), and protein dialysis was repeated.

2.5. Enzyme Activities and Protein Assay. Ppx activity was measured after incubation at $37^{\circ} \mathrm{C}$ for $30 \mathrm{~min}$ in $200 \mu \mathrm{L}$ of $50 \mathrm{mM}$ Tris- $\mathrm{HCl}$ buffer $\mathrm{pH} 8.0,80 \mathrm{mM} \mathrm{KCl}$, and $5 \mathrm{mM}$ $\mathrm{MgCl}_{2}$. The substrates used were polyP 25, polyP 45, polyP $_{65}$, and poly $\mathrm{P}_{75}$. The $\mathrm{P}_{\mathrm{i}}$ released after incubation was measured by the Katewa and Katyare method [19] with modifications. Briefly, $100 \mu \mathrm{L}$ of the reaction mixture was added to $400 \mu \mathrm{L}$ of a solution with $2.5 \%\left(\mathrm{NH}_{4}\right)_{6} \mathrm{Mo}_{7} \mathrm{O}_{24} \cdot\left(\mathrm{H}_{2} \mathrm{O}\right)_{4}$ in $3 \mathrm{~N} \mathrm{H}_{2} \mathrm{SO}_{4}$ and $400 \mu \mathrm{L}$ of $2 \%$ ascorbic acid $/ 2 \%$ hydrazine in $0.1 \mathrm{~N} \mathrm{H}_{2} \mathrm{SO}_{4}$, and the solution was brought to a final volume of $1200 \mu \mathrm{L}$ with triple glass-distilled water. Quantification of free $\mathrm{P}_{\mathrm{i}}$ was performed after $30 \mathrm{~min}$ of incubation at $37^{\circ} \mathrm{C}$ through measurement of the absorbance at $820 \mathrm{~nm}$. One unit of exopolyphosphatase was defined as the amount of enzyme that releases $1 \mathrm{nmol}$ of $\mathrm{P}_{\mathrm{i}}$ per minute at $37^{\circ} \mathrm{C}$.

The phosphotransferase activity was measured after incubation at $37^{\circ} \mathrm{C}$ for $30 \mathrm{~min}$ in $200 \mu \mathrm{L}$ of $50 \mathrm{mM}$ Tris- $\mathrm{HCl}$ buffer $\mathrm{pH} 8.0,200 \mu \mathrm{M}$ ADP, $8 \mu \mathrm{M}$ polyP 65 , and $5 \mathrm{mM}$ of $\mathrm{MgCl}_{2}$ plus $80 \mathrm{mM} \mathrm{KCl}$ or $25 \mathrm{mM} \mathrm{NH}_{4} \mathrm{Cl}$. ATP was determined using the luciferin-luciferase reaction (Kit A-6608, Molecular 
TABle 1: Primers, strains, and plasmids used.

(a)

\begin{tabular}{ll}
\hline Primer & Sequence $5^{\prime} \rightarrow 3^{\prime}$ \\
\hline Upppx & GTCCATATGGACTTGCAAAGC \\
Dwnppx & TGCTTACCGCACGTTGAGGC \\
UpppxN & CATATGCACCAGCACGAGGAC \\
DwnppxC & CTAAGCGCCGACGAGGTCG \\
Up 304 & GTCCATATGGACTTGCAAAGC \\
DWN 304 & GACCAGTTAGTCGTAGAGAAC \\
E126A* & CTCCGGCCGCGAGGCAGCCCGCCTGATC \\
D149A & CCGGCTGGTCAGCGCATCGGCGGCGGC \\
G151A $^{*}$ & GGTCAGCGACATCGCGGCGGCAGCACCG \\
S154A $^{*}$ & CATCGGCGGCGGCGCACCGAGTTCATC \\
E156A $^{*}$ & CGGCGGCAGCACCGAGTTCATCATCGGCC \\
\hline
\end{tabular}

(b)

\begin{tabular}{|c|c|c|}
\hline Strain or plasmid & Genotype and/or description & Reference or source \\
\hline P. aeruginosa $\mathrm{PAO} 1$ & Wild type & WUCG (2005) \\
\hline E. coli XL10-Gold & $\begin{array}{l}\text { Tet }^{\mathrm{r}} \Delta(m c r A) 183 \Delta(m c r C B-h s d S M R-m r r) 173 \text { endA1 supE44 thi-1 recA1 gyrA96 relA1 } \\
\text { lacHte }\left[\mathrm{F}^{\prime} \text { proAB } \text { lacl }^{q} Z \Delta M 15 \text { Tn10 }\left(\mathrm{Tet}^{\mathrm{r}}\right) \text { Amy Cam }{ }^{\mathrm{r}}\right]\end{array}$ & Stratagene \\
\hline E. coli BL21-CodonPlus & E. coli B F- dcmompThsdS(rB- mB-) gal & Promega \\
\hline pCR 2.1-TOPO & $\mathrm{Amp}^{\mathrm{r}} \mathrm{Km}^{\mathrm{r}}$; vector for TA cloning of PCR products & Invitrogen \\
\hline pET-15b & $\mathrm{Amp}^{\mathrm{r}}$, T7 promoter, multiple cloning sites, His-tag coding sequence & Qiagen \\
\hline pCR-ppx & $1.5 \mathrm{~Kb} E c o \mathrm{RI} / \mathrm{NdeI}$ fragment containing the $p p x$ gene cloned into pCR 2.1-TOPO & This study \\
\hline pCR-Nppx & $0.94 \mathrm{~Kb} E c o \mathrm{RI} / \mathrm{NdeI}$ fragment containing the $p p x$ gene cloned into pCR 2.1-TOPO & This study \\
\hline pCR-N303ppx & $\begin{array}{l}0.94 \mathrm{~Kb} E c o \mathrm{RI} / \mathrm{NdeI} \text { fragment containing the N-terminal domain of } p p x \text { gene } \\
\text { cloned into pCR 2.1-TOPO }\end{array}$ & This study \\
\hline pCR-Cppx & $0.56 \mathrm{~Kb} E c o \mathrm{RI} / N d e \mathrm{I}$ fragment containing the $p p x$ gene cloned into pCR 2.1-TOPO & This study \\
\hline pET-ppx & $1.5 \mathrm{~Kb} E c o \mathrm{RI} / N d e \mathrm{I}$ fragment containing the $p p x$ gene cloned into pET-15b & This study \\
\hline $\mathrm{pET}-\mathrm{N} p p x$ & $\begin{array}{l}0.94 \mathrm{~Kb} \text { EcoRI/NdeI fragment containing the N-terminal domain of } p p x \text { gene } \\
\text { cloned into pET-15b }\end{array}$ & This study \\
\hline pET-N303ppx & $\begin{array}{l}0.94 \mathrm{~Kb} E c o \mathrm{RI} / \mathrm{NdeI} \text { fragment containing the N-terminal domain of } p p x \text { gene } \\
\text { cloned into pET-15b }\end{array}$ & This study \\
\hline pET-Cppx & $0.56 \mathrm{~Kb} E c o \mathrm{RI} / N d e \mathrm{I}$ fragment containing the $p p x$ gene cloned into $\mathrm{pET}-15 \mathrm{~b}$ & This study \\
\hline
\end{tabular}

Probes). In sum, $50 \mu \mathrm{L}$ of the mixture described above was added to $450 \mu \mathrm{L}$ of $25 \mathrm{mM}$ tricine $\mathrm{pH} 7.8,5 \mathrm{mM} \mathrm{MgSO}_{4}$, $0.08 \mathrm{mM}$ EDTA, $0.08 \mathrm{mM}$ Na-azide, $10 \mathrm{mM}$ DTT, $0.5 \mathrm{mM}$ D-luciferin, and $10 \mu \mathrm{g}$ of firefly luciferase. The mix was incubated for $10 \mathrm{~min}$ and subsequently the emission spectra were measured between 500 and $650 \mathrm{~nm}$, without excitement, with increments of $1 \mathrm{~nm}$, an integration time of one second, and an emission slit of 10. The fluorescence measurements were performed in a Spex Fluoromax 3 spectrofluorometer (Jovyn-Ivon HORIBA). One unit of phosphotransferase was defined as the amount of enzyme that produces $1 \mathrm{nmol}$ ATP per minute at $37^{\circ} \mathrm{C}$. $K_{M}$ and $V_{\max }$ values were estimated by nonlinear fitting of initial rate data according to the following equations: Hanes $[S] / v=\left([S] / V_{\max }\right)+\left(K_{M} / V_{\max }\right)$; Michaelis-Menten $\left(v=V_{\max }[S\right.$ or $\left.M]\right) / K_{M}+[S$ or $M]$; and/or Hill $\left(\left(v / V_{0}-v\right)=\log K_{0.5}+n \log\right.$ [metal ion]), where $[S]$ and $[M]$ correspond to substrate and metal ion concentrations, respectively. Protein concentration was determined by spectrophotometric measurement at $280 \mathrm{~nm}$ using the correspondent theoretical molar extinction coefficient calculated with the "ProtParam" tool [20] for physicochemical parameter prediction, which is available at the Expasy server (http://www.expasy.com/).

2.6. Molecular Modeling and Molecular Dynamics. The search of $p a \mathrm{Ppx}$ homologues through the use of the BLASTp algorithm resulted in the identification of an ortholog protein in E. coli (ecPpx) with a $41 \%$ identity and $58 \%$ similarity. Two solved structures of this protein are available: PDB: 2FLO, $2.2 \AA$ resolution [14] and PDB: $1 \mathrm{U} 6 \mathrm{Z}, 1.90 \AA$ resolution [13]. According to this, we used $1 \mathrm{U} 6 \mathrm{Z}$ as template because the resolutions of the template had a large impact on the quality of the resulting model. 
A homology model of $p a \mathrm{Ppx}$ in a closed conformation was constructed by comparative modeling using the ICM program [21]. For loop modeling, we performed a conformational sampling of these regions by means of the Sampling Loop module (Monte Carlo) implemented in ICM program.

The final model was validated using ProSA [22], ANOLEA [23], and PROCHECK [24]. Tautomeric states of histidine residues in the model were assigned according to the local environment using the Check Sidechains Plugin from VMD software [25]. The center of mass of the active site (residues Glu ${ }^{126}$, Asp ${ }^{149}$, Gly ${ }^{151}$, Ser ${ }^{154}$, and Glu ${ }^{156}$ ) was measured with VMD software, and in its place an atom of $\mathrm{Mg}^{2+}$, which is an essential cofactor, was added prior to the molecular dynamics.

The model of the $\mathrm{N}-p a \mathrm{Ppx}_{(1-314)}$ in an open state was constructed using the atomic coordinates of PPX/GPPA phosphatase from $A$. aeolicus (aaPpx) in complex with the alarmone ppGpp [26] (PDB: 2J4R). Considering not only the low percentage of identity between $p a \mathrm{Ppx}$ and $a a \mathrm{Ppx}$ [27] but also the homology in secondary structure, the model was constructed by threading using the "one-to-one threading" option of Phyre Server [27] (http://www.sbg.bio .ic.ac.uk/phyre $2 /$ ). The model was obtained with $100 \%$ of confidence and 292 residues of a total of 314 were aligned. Tautomeric states of histidine residues in the model were assigned according to the local environment and $\mathrm{Mg}^{2+}$ ion was located in the active site similarly as we described for the full-length model. The obtained models were subjected to $\mathrm{MD}$ calculations to reach a minimum energy state. For this, the models were embedded in a $15 \AA$ water box, and $\mathrm{KCl} 80 \mathrm{mM}$ was used not only to mimic the optimal conditions for enzyme activity but also to neutralize the total charge of the system. The initial configuration of both systems was optimized using energy minimization followed by an equilibration through a molecular dynamics (MD) simulation in the NPT ensemble at $310^{\circ} \mathrm{K}$ for $1 \mathrm{~ns}$, using a backbone restriction of $0.5 \mathrm{kcal} / \mathrm{mol} \AA$. NAMD program was used to perform all molecular dynamic simulations [28]. The electrostatic interactions were computed with no truncations using the particle mesh Ewald algorithm [29] under periodic boundary conditions.

The DYNDOM server was used to assess the opening degree model in open conformation with respect to the closed conformation [30]. By APBS software the potential electrostatic calculations were performed [31]. The charge and $\mathrm{vdW}$ radius assignment were determined with the software PDB2PQR [32] and the CHARMM force-field. pKa values were calculated using propKa [33].

2.7. Docking Assays. Docking studies were carried out as previously described [34], defining the $\mathrm{N}-p a \mathrm{Ppx}_{(1-314)}$ model in open conformation as receptor. ICM [21] version 3.4 was used and the icmPocketFinder function was employed to detect possible binding sites with a tolerance of 4.6 by default. Tolerance is related to flexibility for sites prediction. The lower the tolerance value the higher the number of pockets predicted and vice versa. The value used was the one recommended by software developers.
Nucleotide ligand inputs were extracted from the PubChem database (http://pubchem.ncbi.nlm.nih.gov/) and the polyP ligand input was constructed by using ICM molecule editor. All ligand charges were assigned by ICM software. All of the structures were protonated and optimized using standard ICM protocols. The thoroughness parameter, which represents the length of the docking simulation, was set at 2.0, as recommended by software developers when metals are present in the docking binding site. For the docking of ADP, the gridbox size was $16.95 \AA \times 19.23 \AA \times 16.05 \AA$, and the center was located at the points $(-5.602 \times 7.844 \times-4.172) \AA$. The binding site was determined by structural alignment with $a a \mathrm{Ppx}$ and the region at which ppGpp is located was used. Thus, the docking pocket was composed of the residues $\mathrm{Asn}^{25}$, His ${ }^{28}, \mathrm{Gly}^{152}, \mathrm{Gly}^{224}$, $\mathrm{Asp}^{272}$, and $\mathrm{Arg}^{274}$. For the docking of polyP $\mathrm{P}_{7}$, the N-paPpx-ADP complex was used as receptor. The binding site was one of those detected by the icmPocketFinder tool and was consistent with the S-shaped canyon described by [14]. The binding site was constituted by the residues $\mathrm{Tyr}^{94} ; \mathrm{Asn}^{95}, \mathrm{Ser}^{122}, \mathrm{Gly}^{123}, \mathrm{Arg}^{124}, \mathrm{Glu}^{126}, \mathrm{Ile}^{130}$, Asp $^{149}$, $\mathrm{Ile}^{150}$, Gly $^{151}$, Gly ${ }^{152}$, Gly ${ }^{153}$, Ser $^{154}$, Glu $^{156}$, Ser $^{170}$, $\mathrm{Gln}^{172}, \mathrm{Ser}^{223}: \mathrm{Gly}^{224}, \mathrm{Arg}^{227}: \mathrm{Ala}^{228}, \mathrm{Leu}^{231}, \mathrm{Gly}^{268}, \mathrm{Ile}^{269}$, $\mathrm{Lys}^{270}, \mathrm{Asp}^{272}, \mathrm{Arg}^{273}, \mathrm{Ile}^{276}, \mathrm{Glu}^{300}, \mathrm{Ala}^{302}, \mathrm{Leu}^{303}, \mathrm{Arg}^{304}$, and $\mathrm{Glu}^{305}$. The gridbox size was $30.26 \AA \times 28.29 \AA \times 25.82 \AA$ and the center was located at the points $(-0.387 \times 1.915 \times$ $-0.669) \AA$.

2.8. Sequence Analysis. To find orthologous proteins, $p a \mathrm{Ppx}$ sequence was used as query in PHMMER against UniProt rp55 database [35]. Sequences with an $E$-value $\leq 10^{-14}$ and a coverage percentage $\geq 77 \%$ were selected. The retrieved sequences (599) were aligned using Clustal $\Omega$ [36, 37]. Residues connecting $\mathrm{N}$-terminal and C-terminal domains (residues 301 to 326) were selected to produce a Logo diagram conservation scheme, through the WebLogo server $[38,39]$ (http://weblogo.berkeley.edu/).

\section{Results}

\subsection{Biochemical Characterization of paPpx}

3.1.1. Cloning and Overproduction of paPPX Variants. The exopolyphosphatase gene of $P$. aeruginosa ( $p p x$, PA5241) was cloned and overproduced as the full-length recombinant protein and also the two peptides representing the N-terminal and C-terminal domains. All recombinant proteins were purified and used to study some of the biochemical properties of the enzyme. The identification of $\mathrm{N}$ - and C-terminal domains was performed considering the crystallographic structure reported by $[13,14]$. The full-length protein comprised 506 aminoacyl residues $\left(p a \mathrm{Ppx}_{(1-506)}\right)$, while the $\mathrm{N}$-terminal domain contained the first 314 aminoacyl residues and the remaining 192 aminoacyl residues corresponded to the C-terminal domain $(\mathrm{N}$ $p a \mathrm{Ppx}_{(1-314)}$ and $\mathrm{C}-p a \mathrm{Ppx}_{(315-506)}$, resp.). The theoretical $\mathrm{MW}$ for $p a \mathrm{Ppx}_{(1-506)}, \mathrm{N}-p a \mathrm{Ppx}_{(1-314)}$, and C-paPpx $\mathrm{P}_{(315-506)}$ were 56,419.33, 34,325.25, and 22,112.10 Da, respectively. Only $p a \mathrm{Ppx}_{(1-506)}$ and $\mathrm{N}-p a \mathrm{Ppx}_{(1-314)}$ were enzymatically active 


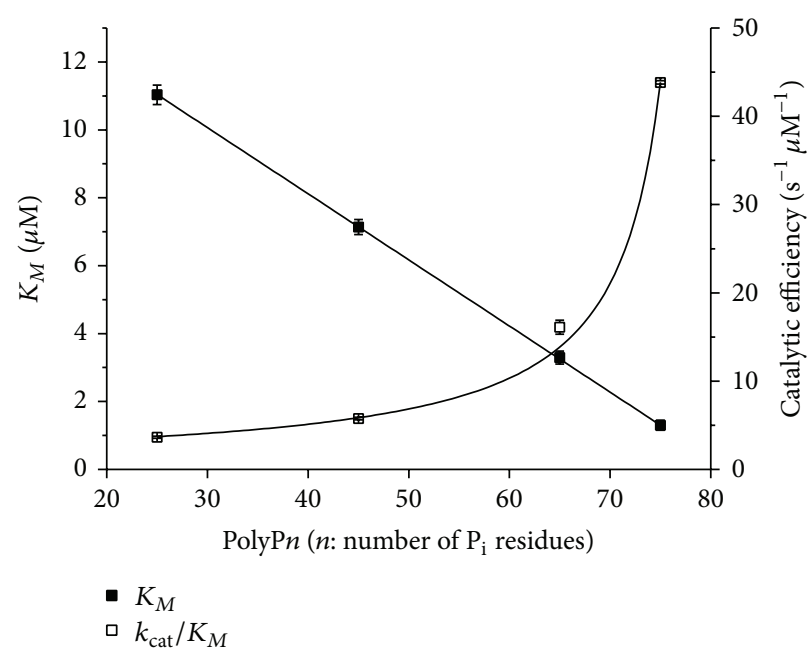

(a)

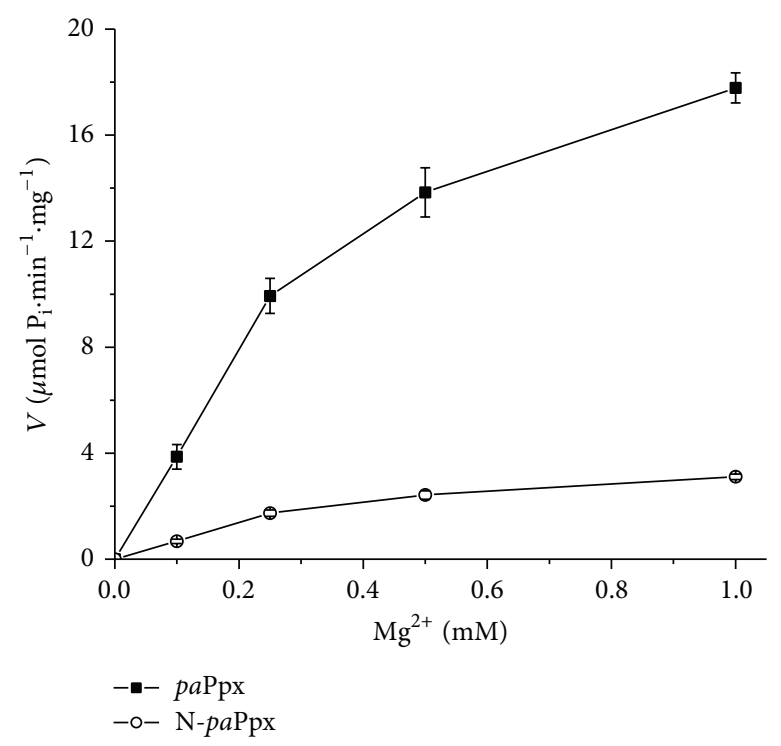

(c)

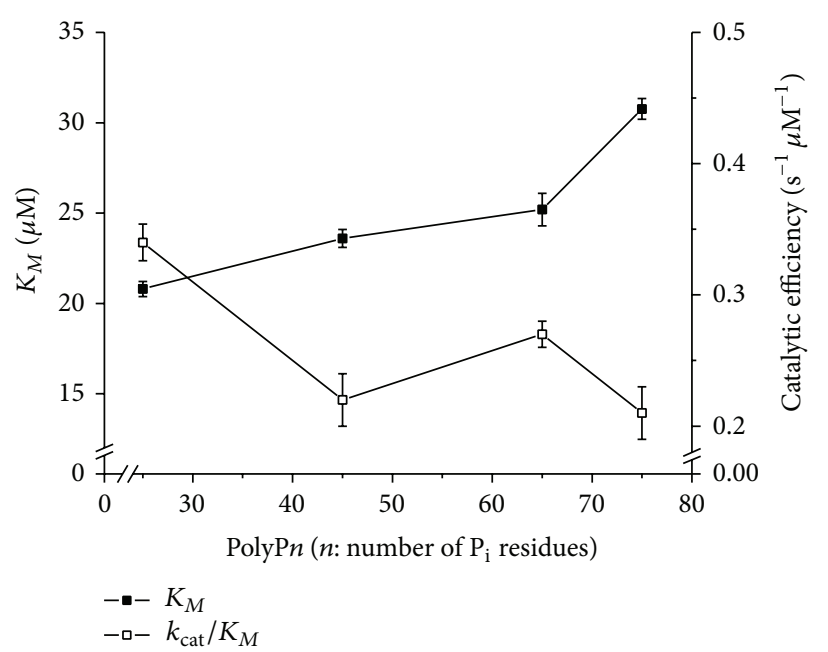

(b)

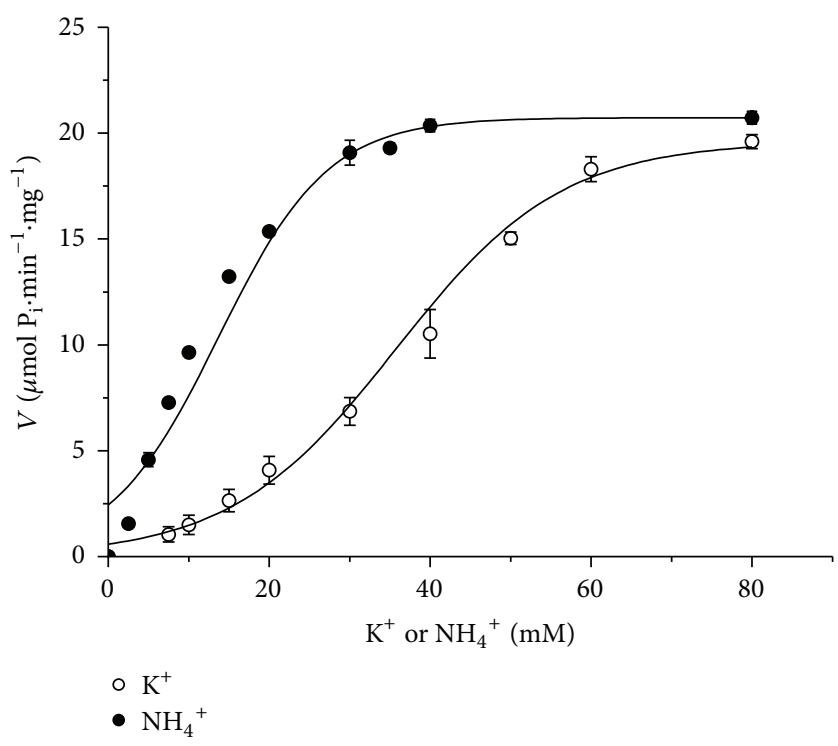

(d)

Figure 1: Kinetic characterization of $p a \mathrm{Ppx}_{(1-506)}$ and N-paPpx$(1-314) . K_{M(\text { app })}(\mathbf{\square})$ and catalytic efficiency $\left(k_{\mathrm{cat}} / K_{M}\right)(\square)$ of $p a \mathrm{Ppx}(\mathrm{a})$ and N$p a \mathrm{Ppx}_{(1-314)}$ (b) for polyP of different chain length. Enzyme activity was measured in Tris- $\mathrm{HCl}$ buffer, $\mathrm{pH} 8.0$, with $\mathrm{Mg}^{2+} 5 \mathrm{mM}$ and $80 \mathrm{mM}$ $\mathrm{K}^{+}$. (c) Saturation curves of $p a \mathrm{Ppx}_{(1-506)}(\mathbf{\square})$ and $\mathrm{N}-\mathrm{paPpx} \mathrm{Px}_{(1-314)}$ ( $\square$ ) with $\mathrm{Mg}^{2+}$. Enzyme activity was measured in Tris- $\mathrm{HCl}$ buffer, $\mathrm{pH} 8.0$, with poly ${ }_{65} 8 \mu \mathrm{M}$ and $80 \mathrm{mM} \mathrm{K}^{+}$. (d) Saturation curves of $p a \mathrm{Ppx}$ with the monovalent ions $\mathrm{K}^{+}(\mathrm{O})$ and $\mathrm{NH}_{4}^{+}(\bullet)$. Enzyme activity was measured in Tris- $\mathrm{HCl}$ buffer, $\mathrm{pH} 8.0$, with $\mathrm{Mg}^{2+} 5 \mathrm{mM}$ and polyP ${ }_{65} 8 \mu \mathrm{M}$.

while C-paPpx ${ }_{(315-506)}$ lacked enzymatic activity. The specific activities of $p a \mathrm{Ppx}_{(1-506)}$ and $\mathrm{N}-\mathrm{paPpx} \mathrm{P}_{(1-314)}$ were 1.49 and $0.38 \mu \mathrm{mol}$ of $\mathrm{P}_{\mathrm{i}} \min ^{-1} \mu \mathrm{mol}^{-1}$ protein, respectively. In order to determine the fragment responsible for the enzymatic activity of $p a \mathrm{Ppx}$, we took into consideration the $\mathrm{N}$-terminal construct obtained by [15], and we produced an N-terminal variant formed by the first 303 aminoacyl residues, named $\mathrm{N}$ $p a \mathrm{Px}_{(1-303)}$, which were found to be inactive.

3.1.2. Effect of the polyP Chain Length on paPpx Activity. The kinetic behavior evaluated and apparent catalytic constants obtained for $p a \mathrm{Ppx}_{(1-506)}$ and $\mathrm{N}-p a \mathrm{Ppx}_{(1-314)}$ are displayed in Figure 1 and summarized in Table 2. With saturating $\mathrm{Mg}^{2+}$ and $\mathrm{K}^{+}$concentrations, $p a \mathrm{Ppx}_{(1-506)}$ increased its affinity for polyP in the following order: polyP ${ }_{25}<$ poly $_{45}<$ polyP $_{65}<$ polyP $\mathrm{P}_{75}$. The decreasing $K_{M(\text { app })}$ values were accompanied by a sharp rise in the catalytic efficiencies, with this behavior being more noticeable with the increment in the length of the substrate chain (Figure 1(a)). This trend did not occur with N$p a \mathrm{Ppx}$ since both $K_{M(\mathrm{app})}$ and catalytic efficiency were similar independently of the length of the polyP chain (Figure 1(b), Table 2). Indeed, the analysis of the results obtained with poly $\mathrm{P}_{75}$ demonstrated that the full-length enzyme presented $K_{M(\text { app) }}$ that was approximately 23 -fold lower than the one of $\mathrm{N}-p a P \mathrm{Px}_{(1-314)}(1.30 \pm 0.05$ versus $30.67 \pm 0.57 \mu \mathrm{M}$, respectively). This behavior was partially reversed by an experiment 
TABLE 2: Kinetic parameters of the full-length $p a \mathrm{Ppx}$ and the N-paPpx variant.

\begin{tabular}{|c|c|c|c|c|c|}
\hline \multirow{2}{*}{ Parameters } & \multirow{2}{*}{ Substrate } & \multicolumn{2}{|c|}{ Hydrolase } & \multicolumn{2}{|c|}{ Transferase } \\
\hline & & $p a \mathrm{Ppx}_{(1-506)}$ & $\mathrm{N}-p a \mathrm{Ppx}_{(1-314)}$ & $p a \mathrm{Ppx}_{(1-506)}$ & $\mathrm{N}-p a \mathrm{Ppx}_{(1-314)}$ \\
\hline$K_{M(\mathrm{app})} \pm \mathrm{SD}, \mu \mathrm{M}$ & polyP $_{75}$ & $1.30 \pm 0.05$ & $30.67 \pm 0.57$ & $\mathrm{nd}^{2}$ & $\mathrm{nd}^{2}$ \\
\hline$k_{\mathrm{cat}}^{1} \pm \mathrm{SD}, \mathrm{s}^{-1}$ & polyP $_{75}$ & $57.02 \pm 1.20$ & $6.69 \pm 0.26$ & $\mathrm{nd}^{2}$ & $\mathrm{nd}^{2}$ \\
\hline$k_{\text {cat }}^{1} / K_{M(\text { app })} \pm \mathrm{SD}, \mathrm{s}^{-1} \mu \mathrm{M}^{-1}$ & polyP $_{75}$ & $43.84 \pm 0.19$ & $0.22 \pm 0.10$ & $\mathrm{nd}^{2}$ & $\mathrm{nd}^{2}$ \\
\hline$K_{M(\text { app })} \pm \mathrm{SD}, \mu \mathrm{M}$ & polyP $_{65}$ & $3.29 \pm 0.19$ & $25.17 \pm 0.90$ & $2.49 \pm 0.20$ & $3.11 \pm 0.10$ \\
\hline$k_{\text {cat }}{ }^{1} \pm \mathrm{SD}, \mathrm{s}^{-1}$ & polyP ${ }_{65}$ & $53.03 \pm 0.90$ & $6.86 \pm 0.17$ & $3.93 \pm 0.31$ & $0.29 \pm 0.04$ \\
\hline$k_{\text {cat }}^{1} / K_{M(\text { app })} \pm \mathrm{SD}, \mathrm{s}^{-1} \mu \mathrm{M}^{-1}$ & polyP 65 & $16.11 \pm 0.80$ & $0.27 \pm 0.01$ & $1.58 \pm 0.13$ & $0.09 \pm 0.01$ \\
\hline$K_{M(\text { app })} \pm \mathrm{SD}, \mu \mathrm{M}$ & polyP $\mathrm{P}_{45}$ & $7.14 \pm 0.12$ & $23.60 \pm 0.50$ & $\mathrm{nd}^{2}$ & $\mathrm{nd}^{2}$ \\
\hline$k_{\mathrm{cat}}^{1} \pm \mathrm{SD}, \mathrm{s}^{-1}$ & polyP $_{45}$ & $41.23 \pm 0.38$ & $5.29 \pm 0.07$ & $\mathrm{nd}^{2}$ & $\mathrm{nd}^{2}$ \\
\hline$k_{\text {cat }}^{1} / K_{M(\text { app })} \pm \mathrm{SD}, \mathrm{s}^{-1} \mu \mathrm{M}^{-1}$ & polyP $_{45}$ & $5.77 \pm 0.15$ & $0.22 \pm 0.01$ & $\mathrm{nd}^{2}$ & $\mathrm{nd}^{2}$ \\
\hline$K_{M(\text { app })} \pm \mathrm{SD}, \mu \mathrm{M}$ & polyP $_{25}$ & $11.03 \pm 0.29$ & $20.83 \pm 0.42$ & $3.11 \pm 0.1$ & $3.36 \pm 0.10$ \\
\hline$k_{\text {cat }}^{1} \pm \mathrm{SD}, \mathrm{s}^{-1}$ & polyP $_{25}$ & $40.20 \pm 1.34$ & $7.26 \pm 0.16$ & $4.28 \pm 0.27$ & $0.31 \pm 0.02$ \\
\hline$k_{\text {cat }}^{1} / K_{M(\text { app })} \pm \mathrm{SD}, \mathrm{s}^{-1} \mu \mathrm{M}^{-1}$ & polyP $\mathrm{P}_{25}$ & $3.64 \pm 0.12$ & $0.35 \pm 0.01$ & $1.38 \pm 0.12$ & $0.09 \pm 0.01$ \\
\hline
\end{tabular}

Values are means \pm SD of at least three experiments performed independently.

${ }^{1}$ For $k_{\text {cat }}$ determination, $p a \mathrm{Ppx}$ the full-length protein was considered as a dimer and $\mathrm{N}-\mathrm{p} a \mathrm{Ppx}$ was considered as a monomer.

${ }^{2}$ nd: not determined.

of complementation, where a mixture of $\mathrm{N}-\mathrm{paPpx}_{(1-314)} / \mathrm{C}$ $p a \mathrm{Ppx}_{(315-506)}$, in a 1:10 ratio, produced an active enzyme with higher affinity for the substrate polyP $\mathrm{P}_{75}$. The $K_{M(\text { app }}$ value measured in the mix was $11 \pm 2 \mu \mathrm{M}$, which represented an increase of $\approx 2.3$-fold.

\subsubsection{Ion Dependence of Ppx Activity}

Divalent Ions Dependence. We studied the behavior of the full-length $p a \mathrm{Ppx}_{(1-506)}$ and $\mathrm{N}-p a \mathrm{Ppx}_{(1-314)}$ against different concentration of divalent ions such as $\mathrm{Mg}^{2+}, \mathrm{Zn}^{2+}, \mathrm{Ca}^{2+}$, and $\mathrm{Mn}^{2+}$ as effectors, in presence of a saturating concentration $(8 \mu \mathrm{M})$ for the substrate poly $\mathrm{P}_{65}$. The activation of both enzyme variants by $\mathrm{Mg}^{2+}$ was similar and showed no inhibition at high concentrations of this ion (Figure 1(c)). This result differed from the one obtained by $[36,37]$ for the ecPpx activity that found a sharp decrease in the activity with $\mathrm{Mg}^{2+}$ concentrations of $1 \mathrm{mM}$ and higher.

The values of $K_{0.5(\mathrm{app}) \mathrm{Mg}^{2+}}$ in $p a \mathrm{Ppx}_{(1-506)}$ and $\mathrm{N}$ $p a \operatorname{Ppx}_{(1-314)}$ were $0.30 \pm 0.02 \mathrm{mM}$ and $0.28 \pm 0.02 \mathrm{mM}$, respectively. $\mathrm{Zn}^{2+}$ was able to activate the enzyme only $20 \%$ compared to $\mathrm{Mg}^{2+}$, whereas the activation by $\mathrm{Ca}^{2+}$ and $\mathrm{Mn}^{2+}$ was negligible ( $3 \%$ and $2 \%$, resp.). These data, added to the fact that the interaction between $p a \mathrm{Ppx}_{(1-506)}$ and $\mathrm{Mg}^{2+}$ occurs in the $\mathrm{N}$-terminal domain, showed a clear preference of the enzyme for $\mathrm{Mg}^{2+}$ without inhibition by ion concentration up to $10 \mathrm{mM}$.

As expected, $\mathrm{K}^{+}$was a nonessential activator of $p a \mathrm{Ppx}$. This result is in good agreement with other studies performed on Ppxs $[11,15]$. To assess the net effect of $\mathrm{Mg}^{2+}$, we performed a saturation curve of the divalent ion with the full-length enzyme, with and without $\mathrm{K}^{+}$. The presence of $\mathrm{K}^{+}$did not affect the affinity of the enzyme for $\mathrm{Mg}^{2+} ;\left(K_{0.5(\mathrm{app}) \mathrm{Mg}^{2+}}\right.$ values were similar: $0.30 \pm 0.02 \mathrm{mM}\left(\mathrm{K}^{+}\right)$and $0.33 \pm 0.01 \mathrm{mM}$ (no $\left.\mathrm{K}^{+}\right)$).
Monovalent Ions Dependence. Considering the activation produced by $\mathrm{K}^{+}$in the activity of $p a \mathrm{Ppx}_{(1-506)}$, we decided to test the effect of other monovalent ions. We observed that $\mathrm{Li}^{+}$and $\mathrm{Na}^{+}$presented no effects on enzyme activity while $\mathrm{NH}_{4}{ }^{+}, \mathrm{K}^{+}, \mathrm{Rb}^{+}$, and $\mathrm{Cs}^{+}$were activators of $p a \mathrm{Ppx}_{(1-506)}$. Taking into account the physiological relevance of $\mathrm{NH}_{4}^{+}$ and $\mathrm{K}^{+}$, saturation curves of $p a \mathrm{Ppx}$ with these ions were performed in the presence of $8 \mu \mathrm{M}$ of polyP 65 and $5 \mathrm{mM}$ of $\mathrm{Mg}^{2+}$. The curves obtained with $\mathrm{NH}_{4}{ }^{+}$and $\mathrm{K}^{+}$were sigmoid and reached their maximum activity at concentrations of $30 \mathrm{mM}$ and $80 \mathrm{mM}$, respectively (Figure $1(\mathrm{~d})$ ). $\mathrm{K}_{0.5(\mathrm{app}) \mathrm{NH}_{4}{ }^{+}}$ was $10 \pm 0.4 \mathrm{mM}$ and $K_{0.5(\mathrm{app}) \mathrm{K}^{+}}$was $42 \pm 0.5 \mathrm{mM}$ for $\mathrm{K}^{+}$.

In view of the activation of $p a \mathrm{Ppx}_{(1-506)}$ by $\mathrm{NH}_{4}{ }^{+}$, we tested alkylammonium ions with different degrees of methylation as activators. We found that activation decreased as the number of methyl substituents increased. Considering the $\mathrm{NH}_{4}{ }^{+}$activation as $100 \%$, the percentages of activity with methylamine, dimethylamine, and trimethylamine were of 28,9 , and $5 \%$, respectively. Tetramethylammonium was not an activator of $p a \mathrm{Ppx}_{(1-506)}$.

3.2. Phosphotransferase Activity. Since the Ppx/GPPA from $A$. aeolicus acts on a nucleotide (pppGpp) and the structure of this enzyme in presence of the product (ppGpp) (PDB: $2 J 4 R)$ is available $[17,26]$, we hypothesized that in the active site of $p a \mathrm{Ppx}$ there could be enough space to bind a nucleotide molecule such as ADP; thus we decided to test the $p a \mathrm{Ppx}$ as a polyphosphate:ADP phosphotransferase. The production of ATP from polyP and ADP was measured in $p a \mathrm{Ppx}_{(1-506)}$ and $\mathrm{N}-p a \mathrm{Ppx}_{(1-314)}$ with polyP lengths of 25 and 65 residues as substrates. Both variants presented phosphotransferase activity and, similarly to results obtained for the phosphatase activity, the N-paPpx $\mathrm{P}_{(1-314)}$ had a lower catalytic efficiency (Figure 2). The catalytic parameters of the phosphotransferase activity compared to those of the phosphatase activity are listed in Table 2 . In both variants, 
TABLE 3: Effect of mono- and divalent cations on phosphotransferase activity of the full-length $p a \mathrm{Ppx}$ and of the N-paPpx variant.

\begin{tabular}{lcc}
\hline Mono- or divalent cations & $\begin{array}{c}p a \mathrm{Ppx}_{(1-506)} \\
\text { Phosphotransferase activity } \\
\left(\mathrm{nmol} \mathrm{ATP} \cdot \mathrm{min}^{-1} \cdot \mathrm{mg}^{-1}\right)\end{array}$ & $\begin{array}{c}\mathrm{N}-\mathrm{paPpx}(1-314) \\
\text { Phosphotransferase activity } \\
\left(\mathrm{nmol} \mathrm{ATP} \cdot \mathrm{min}^{-1} \cdot \mathrm{mg}^{-1}\right)\end{array}$ \\
\hline $\mathrm{Mg}^{2+}(5 \mathrm{mM})$ & $193.4 \pm 6.6$ & $39.3 \pm 1.2$ \\
$\mathrm{~K}^{+}(80 \mathrm{mM})$ & $1.2 \pm 0.1$ & $0.9 \pm 0.1$ \\
$\mathrm{Mg}^{2+} / \mathrm{K}^{+}(5 \mathrm{mM} / 80 \mathrm{mM})$ & $187.6 \pm 9.4$ & $38.7 \pm 2.5$ \\
$\mathrm{NH}_{4}^{+}(25 \mathrm{mM})$ & $2.1 \pm 0.9$ & $1.6 \pm 0.4$ \\
$\mathrm{Mg}^{2+} / \mathrm{NH}_{4}^{+}(5 \mathrm{mM} / 25 \mathrm{mM})$ & $189 \pm 10.1$ & $42.9 \pm 2.9$ \\
\hline
\end{tabular}

Values are means \pm SD of at least three experiments performed independently.

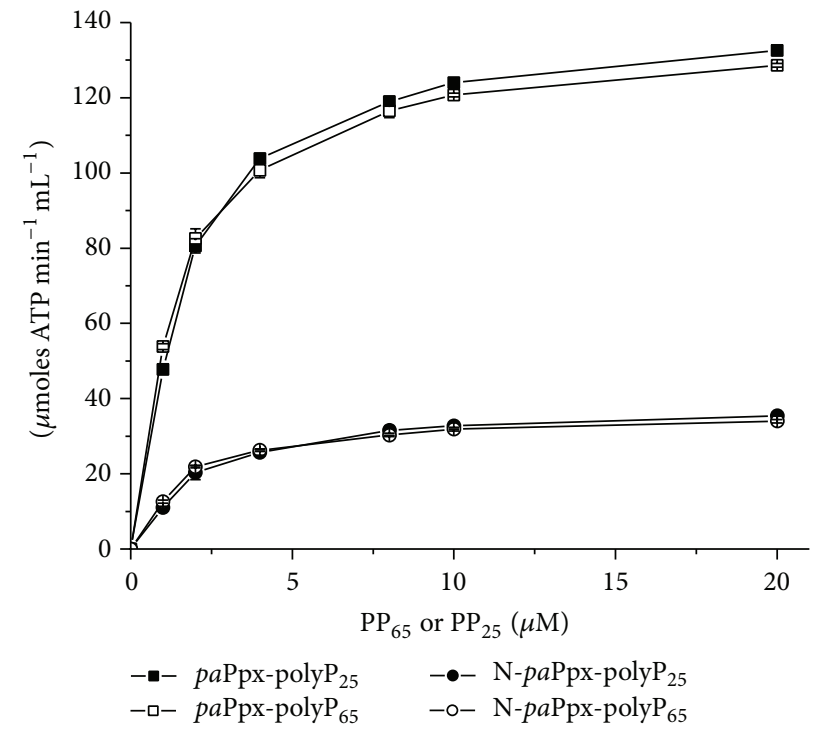

FIGURE 2: Phosphotransferase activity. Phosphotransferase activity of $p a \operatorname{PPX}_{(1-506)}(\bullet, \bigcirc)$ and $\mathrm{N}-p a \operatorname{Ppx}_{(1-314)}(\mathbf{\square}, \square)$. Activity was measured with two substrates: $\operatorname{polyP}_{25}(\bullet, \mathbf{\bullet})$ and polyP $65(\mathrm{O}, \square)$. Assayed conditions were Tris-HCl buffer, $\mathrm{pH}$ 8.0, $200 \mu \mathrm{M}$ ADP, $5 \mathrm{mM} \mathrm{Mg}^{2+}$, and $80 \mathrm{mM} \mathrm{K}^{+}$.

the phosphotransferase activity was independent of the polyP chain length since the $K_{M(\text { app })}$ and the $K_{\text {cat }}$ were in the same order of magnitude for the poly $\mathrm{P}_{25}$ or the poly $\mathrm{P}_{65}$.

The phosphotransferase activity was dependent on $\mathrm{Mg}^{2+}$; however, the $K_{0.5(\mathrm{app}) \mathrm{Mg}^{2+}}$ value was approximately half that observed for phosphatase activity. The fact that the phosphotransferase activity was insensitive to the addition of $\mathrm{K}^{+}$ or $\mathrm{NH}_{4}{ }^{+}$(Table 3) constituted an interesting finding. On the other hand, the affinity for ADP was independent of the length of the polyP chain used as phosphate donor. The $K_{M(\text { app) }}$ value was in the order of $90 \mu \mathrm{M}$ for both substrates and variants tested (data not shown).

\subsection{In Silico Studies}

3.3.1. Molecular Modeling of paPpx: Open and Closed Conformation. Initially, we modeled a full-length paPpx by comparative modeling, using the atomic coordinates of the crystal structure of ecPpx [13] (PDB: 1U6Z). The template structure shared $41 \%$ of identity and $58 \%$ of similarity with $p a \mathrm{Px}_{(1-506)}$ and was reported in what the authors named "closed conformation." In second place, we modeled the Nterminal domain of paPpx in the "open conformation" based on the atomic coordinates of aaPpx [26] (PDB: 2J4R).

Based on the homology in secondary structure and in spite of the low identity level between $p a \mathrm{Ppx}$ and $a a \mathrm{Ppx}$ $(27 \%)$, the model was constructed by threading using the "one-to-one threading" option of Phyre Server [27]. The model was obtained with $100 \%$ of confidence and 292 residues of 314 were aligned. The resulting structures had an architecture that is characteristic within the actin-like ATPase domain superfamily, composed of two subdomains in the $\mathrm{N}$-terminal domain and other two subdomains in the Cterminal (in the case of full-length $p a \mathrm{Ppx}$ ). In the proteins of this family, movements of up to $30^{\circ}$ were described to be related to the catalytic function of the enzymes. In $a a \mathrm{Ppx}$ a rotational movement of $22.5^{\circ}$ between both domains around a single hinge region was described, indicating the access to the active site, located at the interface between domains. Kristensen and collaborators [26] described the access to the active site through a "butterfly-like" cleft opening. Figure 3(a) shows the superimposition of $\mathrm{N}$-terminal domains of the models of $p a \mathrm{Ppx}$ in the open and closed conformations. A rotation of $24^{\circ}$ between subdomains I and II was detected by DYNDOM server between both structures [30], with $\mathrm{G}^{123}: \mathrm{R}^{124}$ and $\mathrm{R}^{304}: \mathrm{E}^{305}$ as bending residues.

3.3.2. Active Site. By homology to what has been described in other exopolyphosphatases $[13,14,17,26]$, the active site of $p a \mathrm{Ppx}$ is formed by residues $\mathrm{E}^{126}, \mathrm{D}^{149}, \mathrm{G}^{151}, \mathrm{~S}^{154}$, and $\mathrm{E}^{156}$. We confirmed the role of these amino acids in the active site of $p a \mathrm{Ppx}_{(1-506)}$ by performing nonconserved site-directed mutations, replacing individually each of these residues by alanine. The two activities, phosphatase and phosphotransferase, were measured and the release of both $\mathrm{P}_{\mathrm{i}}$ and ATP production was severely affected (Table 4).

3.3.3. Docking with polyP and $A D P$. After finding that $p a \mathrm{Ppx}$ can also act as a phosphotransferase, we were interested in proposing a three-dimensional model with polyP as $\mathrm{P}_{\mathrm{i}}$ donor and ADP as the acceptor. Therefore, we performed docking assays that complemented our biochemical findings.

Sequential docking in the open conformation of N$p a \mathrm{Ppx}_{(1-314)}$ was carried out. First, docking was performed 


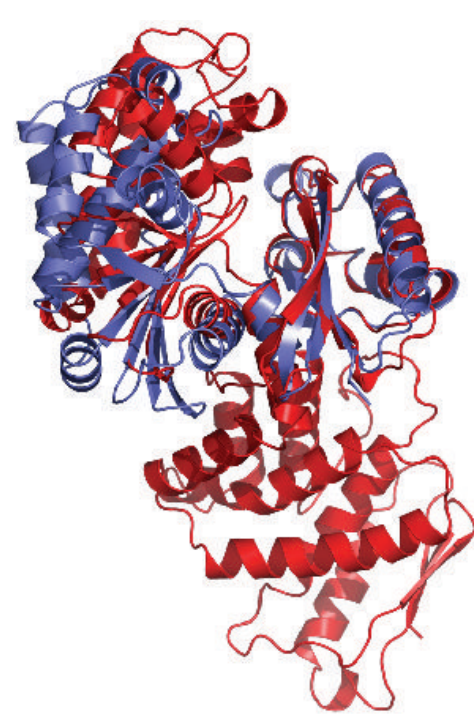

(a)

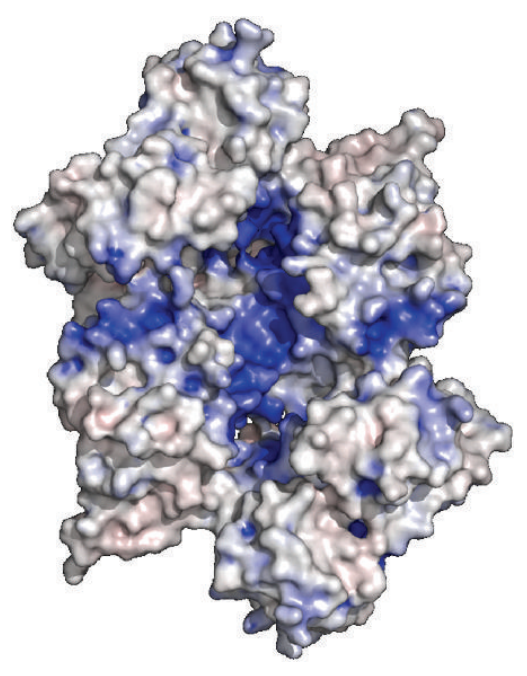

(c)

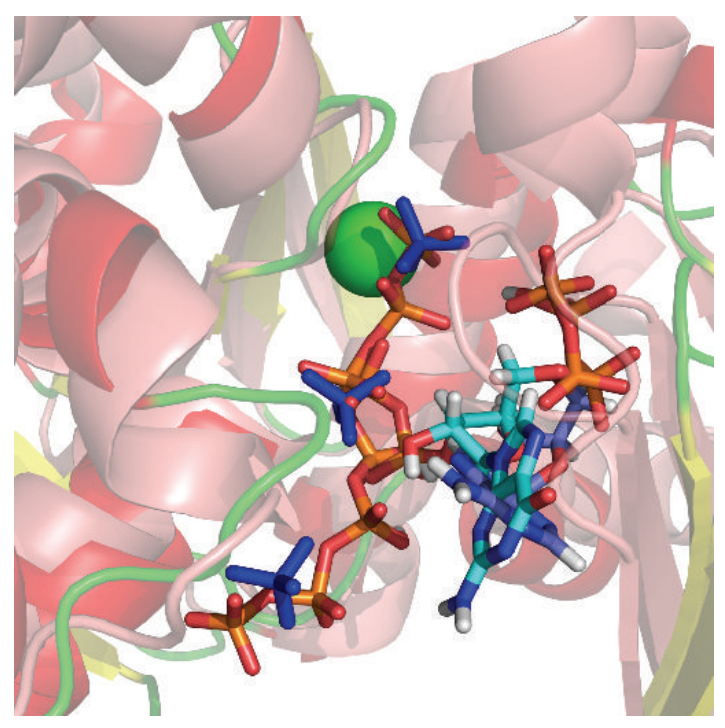

(b)
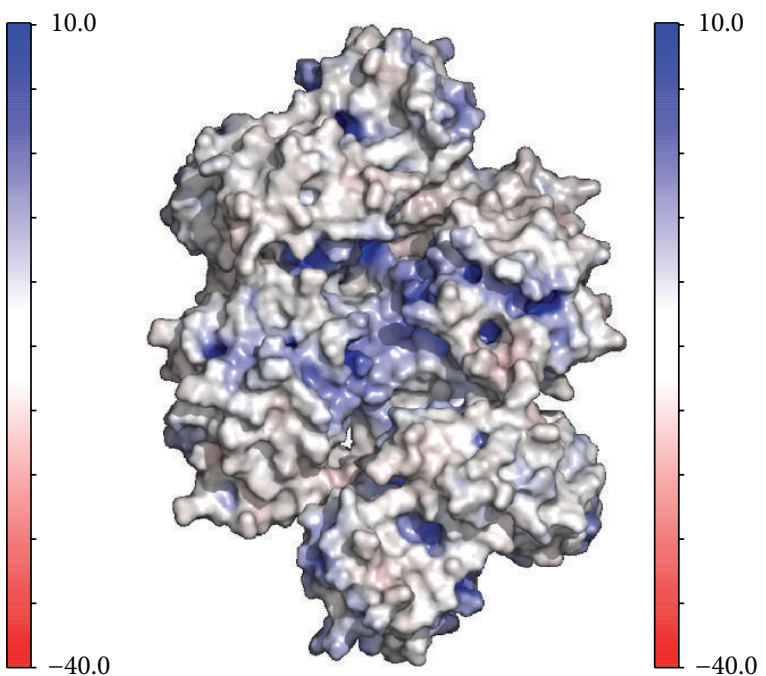

(d)

FIgURE 3: In silico studies. (a) Cartoon representation of the $p a \mathrm{Ppx}_{(1-506)}$ model in closed conformation superimposed with the $\mathrm{N}-p a \mathrm{Ppx}(1-314)$ model in open conformation. (b) Cartoon representation of the complex N-paPpx-ADP-poly $\mathrm{P}_{7}$ obtained by docking. A superimposition with sulfate ions (blue) of PDB: 1U6Z and ppGpp (Cyan) of PDB: 2J4R is shown. $\mathrm{Mg}^{2+}$ ion is represented as a green sphere. ((c) and (d)) Electrostatic potential calculated using APBS of $e c \mathrm{Ppx}(\mathrm{c})$ and $p a \mathrm{Ppx}$ (d) and mapped to the molecular surface, highlighting regions of positive potential.

with 7 residues long polyP $\left(\operatorname{poly}_{7}\right)$ chain in presence of $\mathrm{Mg}^{2+}$. Among the pockets detected by the IcmPocketFinder tool there was one that covered all the cleft, which was postulated to be opened or closed with $\mathrm{N}$-terminal domain movements. Considering that this region was consistent with the location of the active site and the putative polyP binding sites described by $[13,14]$, we used this pocket for the docking assays. After the selection of the best conformer, the NpaPpx-poly $\mathrm{P}_{7}$ complex was used as the receptor molecule to perform docking with ADP. The possible conformations adopted by the nucleotide seemed to be led by the $\mathrm{P}_{\mathrm{i}}$ moiety which is always located in the same position, and the guanosine group showed some degree of rotation resulting in slightly different positions inside the same binding site.
The location of the terminal $\mathrm{P}_{\mathrm{i}}$ nearby the $\mathrm{Mg}^{2+}$ atom was consistent with the proposed catalytic mechanism. It was also possible to see the rest of the polyP chain running along the cleft. The final complex is shown in Figure 3(b). The residues in the $4 \AA$ radius of the ligands were $\mathrm{Tre}^{95}, \mathrm{Asn}^{95}$, $\mathrm{Arg}^{98}, \mathrm{Ser}^{122}, \mathrm{Gly}^{123}, \mathrm{Arg}^{124}, \mathrm{Glu}^{126}$, $\mathrm{Ile}^{150}, \mathrm{Gly}^{151}, \mathrm{Gly}^{152}$, Gly $^{153}, \operatorname{Ser}^{154}, \mathrm{Glu}^{156}, \mathrm{Ser}^{170}$, Leu ${ }^{171}, \mathrm{Gln}^{172}, \mathrm{Ser}^{223}, \mathrm{Gly}^{225}$ $\mathrm{Tre}^{225}, \mathrm{Arg}^{227}, \mathrm{Ala}^{228}$, Leu ${ }^{231}, \mathrm{Lys}^{270}$, and $\mathrm{Arg}^{273}$. polyP was stabilized by $\mathrm{H}$-bonds with Gly ${ }^{153}$, $\mathrm{Ser}^{154}$, and $\mathrm{Gly}^{224}$ and saline bridges with $\mathrm{Arg}^{227}$, $\mathrm{Lys}^{270}$, and $\mathrm{Arg}^{273}$. Meanwhile, in the ADP, the ribose established an $\mathrm{H}$-bond with $\mathrm{Arg}^{304}$ and $\alpha$ and $\beta$ phosphates established an H-bond with $\operatorname{Ser}^{24}$ and $\mathrm{Asn}^{25}$. By comparison with the approach of Alvarado and 
TABLE 4: Hydrolase and transferase activity of mutated variants of paPpx.

\begin{tabular}{|c|c|c|c|c|}
\hline \multirow[b]{2}{*}{ Ppx variant } & \multicolumn{2}{|c|}{ Hydrolase } & \multicolumn{2}{|c|}{ Transferase } \\
\hline & $\begin{array}{l}\text { Specific } \\
\text { activity }^{1}\end{array}$ & $\%$ & $\begin{array}{l}\text { Specific } \\
\text { activity }^{2}\end{array}$ & $\%$ \\
\hline$p a \mathrm{Ppx}_{(1-506)}$ & $1.49 \pm 4 E^{-2}$ & 100 & $10.92 \pm 4 E^{-1}$ & 100 \\
\hline $\mathrm{N}-p a \mathrm{Ppx}_{(1-314)}$ & $0.38 \pm 6 E^{-3}$ & 25.5 & $1.34 \pm 4 E^{-2}$ & 12.3 \\
\hline$E 126 A^{3}$ & $0.016 \pm 5 E^{-5}$ & 1.1 & $0.21 \pm 9 E^{-4}$ & 1.9 \\
\hline $\mathrm{D} 149 \mathrm{~A}^{3}$ & $0.056 \pm 7 E^{-5}$ & 3.8 & $0.31 \pm 4 E^{-4}$ & 2.8 \\
\hline$S 154 A^{3}$ & $0.079 \pm 1 E^{-4}$ & 5.3 & $0.46 \pm 1 E^{-3}$ & 4.2 \\
\hline G151A ${ }^{3}$ & $0.105 \pm 4 E^{-4}$ & 7.1 & $0.69 \pm 2 E^{-3}$ & 6.3 \\
\hline $\mathrm{E} 156 \mathrm{~A}^{3}$ & $0.034 \pm 2 E^{-4}$ & 2.3 & $0.23 \pm 9 E^{-4}$ & 2.1 \\
\hline
\end{tabular}

Values are means \pm SD of at least three experiments performed independently. Both activities were measured with $8 \mu \mathrm{M}$ polyP ${ }_{65}, 5 \mathrm{mM}$ of $\mathrm{Mg}^{2+}$, and $80 \mathrm{mM}$ of $\mathrm{K}^{+}$

${ }^{1} \mu \mathrm{mol}$ of $\mathrm{P}_{\mathrm{i}} \min ^{-1} \mu \mathrm{mol}$ protein ${ }^{-1}$

${ }^{2} \mathrm{nmol}$ of ATP $\min ^{-1} \mu$ mol protein ${ }^{-1}$.

${ }^{3}$ Mutated variants are all full-length $p a \mathrm{Ppx}_{(1-506)}$.

collaborators [13], the model of N-paPpx ${ }_{(1-314)}$ in the open conformation with both ligands coexisting in the cleft was aligned with the $\mathrm{N}$-terminal domain of ecPpx, which had $\mathrm{SO}_{4}{ }^{2-}$ ions in the cleft. It is assumed that these ions describe a path for the polyP chain. The criterion for alignment was based on the active site residues, which remain in the same position regardless of the state of the conformation (opened or closed). This superimposition is shown in Figure 3(b). We also structurally aligned the complex obtained by docking with $a a \mathrm{Ppx}$ and it is noted that phosphates residues of $3^{\prime}$ are superimposable with the polyP residue while the $5^{\prime}$ phosphates residues are superimposable with $5^{\prime}$ phosphates of ADP (Figure 3(b)).

3.3.4. Electrostatic Potential Calculations. A key aspect that remains to be characterized in the $p a \mathrm{Ppx}$ is the binding site of the polyP chain. Considering that the substrate of Ppx is a polyanion, it is possible that coulombic interactions govern the union between polyP and Ppx. Taking into account the relationship that may exist between the electrostatic potential of Ppx and the area where the polyP would bind [14], we performed the calculations of the electrostatic potential in $p a \mathrm{Ppx}_{(1-506)}$ model and ecPpx. These results are shown in Figures 3(c) and 3(d). It is notorious that in $p a \mathrm{Ppx}$ the electropotential was much less positive than in ecPpx, especially around the cleft.

\section{Discussion}

We have recently demonstrated the involvement of Ppx in the pathogenesis of $P$. aeruginosa [8]. This finding led us to investigate in greater detail the enzyme from a biochemical approach. Previous studies performed by several authors have established that the ecPpx is composed of two independently folded domains: $\mathrm{N}$ - and C-terminal domains [13-15]. Based on this knowledge, we constructed several recombinant variants of $p a \mathrm{Ppx}$ : $p a \mathrm{Ppx}_{(1-506)}, \mathrm{N}-p a \mathrm{Ppx}_{(1-314)}$, $\mathrm{N}-p a \mathrm{Ppx}_{(1-303)}$, and C-paPpx $\mathrm{P}_{(315-506)}$.
Our results indicate that the catalytic moiety of $p a \mathrm{Ppx}$ was localized in the $\mathrm{N}$-terminal portion formed by the first 314 amino acid residues. Consistently with this, Alvarado and collaborators [13] also found that the N-terminal region of ecPpx, formed by 320 amino acid residues, was responsible for the catalytic activity. However, Bolesch and Keasling [15] did not find ecPpx activity in the N-terminal portion after limited proteolysis with Staphylococcus aureus V8 protease (Glu-C). A possible explanation for the discrepancy between these results may lie in the construction of the $\mathrm{N}$-terminal variants. The peptide ${ }^{304}$ EMEGRFRHQDVRSRTAS ${ }^{320}$ located in the carboxyl end of the $\mathrm{N}$-terminal variant constructed by Alvarado and collaborators [13] was absent in the Nterminal variant produced by Bolesch and Keasling [15]. This peptide constitutes a part of the connecting segment between domains II and III. When we compared the Cterminal end of the N-ecPpx ${ }_{295-321}$ and $\mathrm{N}-\mathrm{paPpx}_{301-326}$, we obtained a high degree of identity between these two enzymes (Figure 4(a)). The analysis of residue conservation through multiple sequence alignment showed that the residues forming the last $\alpha$-helix of the $\mathrm{N}$-terminal domain (297-304 in ecPpx and 303-310 in paPpx) are conserved (Figure 4(b)). Structurally this helix is stepped between subdomains I and II of the N-terminal domain near the active site and constitutes a sort of separation between both subdomains (Figure 4(c)). We propose that this $\alpha$-helix is involved in ligand interaction and/or folding of $p a \mathrm{Ppx}$, since no enzymatic activity was detected in the variant $\mathrm{N}-\mathrm{paPpx}(1-303)$. Likely, the lack of this helix may prevent the proper folding of the domain or it may cause a disruption affecting the active site, resulting in loss of activity.

Although $\mathrm{N}-p a \mathrm{Ppx}_{(1-314)}$ presented enzymatic activity, it had no preference for long polyP chains, and its $K_{M(\text { app })}$ and catalytic efficiency presented roughly the same values for all tested substrates. These results strongly suggest that the C-terminal domain is important for the recognition and/or interaction with long polyP chains. These findings are in concordance with those reported by [15] that stated that Cterminal domain of ecPpx is involved in the recognition and processivity of long polyP chains.

The activity of $p a \mathrm{Ppx}$ was dependent on $\mathrm{Mg}^{2+}$, as it was demonstrated for other Ppxs [1]. Studies performed with the ecPpx showed that the maximum activity was achieved in presence of $\mathrm{Mg}^{2+} 1 \mathrm{mM}$ [35] while higher concentrations produced a sharp inhibition. It was reported for the Ppx of the archaea bacterium Sulfolobus solfataricus that $\mathrm{Mn}^{2+}$ is needed as an activator in concentrations $\approx 1 \mathrm{mM}$ and that $\mathrm{Mg}^{2+}$ is needed to a lesser extent $[38,39]$. Furthermore, for the mitochondrial Ppx of Saccharomyces cerevisiae [40] the requirements determined for divalent metals were similar: about $1 \mathrm{mM}$ of $\mathrm{Mg}^{2+}, \mathrm{Mn}^{2+}$, and $\mathrm{Co}^{2+}$, including $\mathrm{Zn}^{2+}$ to a lesser extent. Results of these reports suggest similar catalytic mechanisms. Our results related to the activation of $p a \mathrm{Ppx}$ by divalent cations are in good agreement with the work of Dudev and Lim [41], who demonstrated that the $\mathrm{Mg}^{2+}$ binding sites are not often specific for $\mathrm{Mg}^{2+}$ and that $\mathrm{Zn}^{2+}$ may replace it in that location. We found that $\mathrm{K}^{+}$and $\mathrm{NH}_{4}^{+}$ are nonessential activators of $p a \mathrm{Ppx}$. Our results considerably 


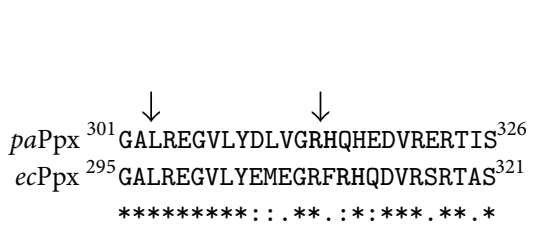

(a)

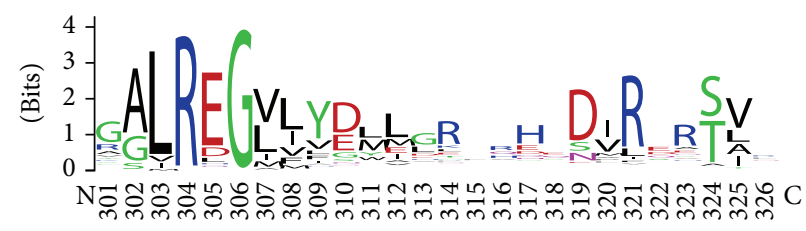

(b)

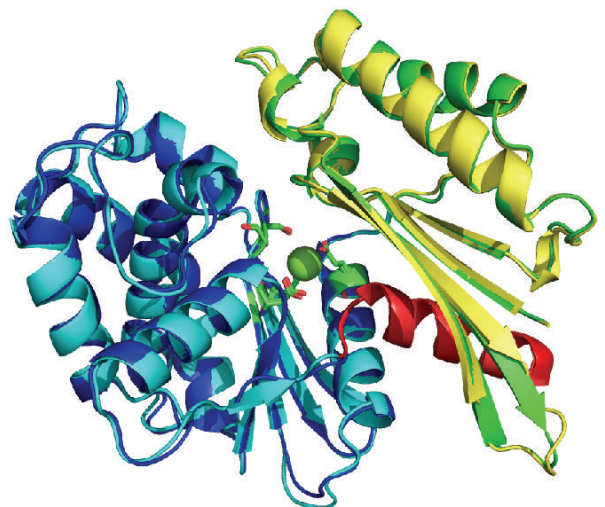

(c)

FIGURE 4: Sequence alignment of the connecting peptide between subdomains II and III. (a) Alignment of the end of N-ecPpx $295-321$ and $\mathrm{N}-\mathrm{paPpx}_{301-326}$. Sequences were aligned using ClustalX. The arrow indicates the cleavage site for both $\mathrm{N}$-terminal variants used in this work $\mathrm{N}-p a \mathrm{Ppx}_{(1-314)}$ and $\mathrm{N}-p a \mathrm{Ppx}_{(1-303)}$. (b) Logo for $p a \mathrm{Ppx}$ peptide 301-326. Residues 303-315 constitute the last $\alpha$-helix of N-terminal domain. Residues 316-320 constitute the loop connecting the N-terminal domain to the C-terminal domain. Residues 321-326 are forming the first $\alpha$-helix of C-terminal domain. 599 sequences aligned with Clustal $\Omega$ were used to create the logo. (c) Cartoon representation of the closed conformation of N-paPpx in superimposition to N-ecPpx (PDB: 1U6Z). Residues of active site are represented as sticks and $\mathrm{Mg}^{2+}$ ion is represented as a green sphere. Color references: N-ecPpx: green: subdomain I, blue: subdomain II, and red: $\alpha$-helix formed by residues $297-$ 310. N-paPpx: yellow: subdomain I, cyan: subdomain II, and coral: $\alpha$-helix formed by residues 303-315.

differ from those reported for the ecPpx [36, 37], where more than twice the amount of $\mathrm{K}^{+}$was necessary to achieve the maximal activity $(175 \mathrm{mM}$ versus $80 \mathrm{mM})$ and where ammonium sulfate was not considered as an activator of the E. coli enzyme. We believe that the lack of activation by ammonium sulfate may be due to the presence of sulfate ions which can bind to the enzyme and mimic the phosphate residues of the substrate, thus blocking the activity. The crystal structure reported by [13] also supports our inference, since numerous sulfate ions were bound to the enzyme, which led the authors to postulate that the presence of these ions represented the polyP chain path.

The whole data presented confirm that $p a \mathrm{Ppx}$ activity is dependent on $\mathrm{Mg}^{2+}$ and is stimulated by $\mathrm{K}^{+}$in a similar manner to ecPpx. Our present study also adds a new perspective to previous results, with the finding that $\mathrm{NH}_{4}{ }^{+}$can act as a direct activator of $p a \mathrm{Ppx}$ at lower concentrations than $\mathrm{K}^{+}$. It was demonstrated that bacteria may accumulate transiently polyP during the stationary phase and especially under conditions of nitrogen and $\mathrm{P}_{\mathrm{i}}$ limitation and during osmotic stress [9]. It is also known that $\mathrm{K}^{+}$is the most prevalent cation in the cytoplasm and it becomes more concentrated as the osmolarity increases [42]. Therefore, in a hyperosmolar condition, the increase of $\mathrm{K}^{+}$is useful to activate directly the paPpx. As the $\mathrm{NH}_{4}{ }^{+}$concentration is limited or in the presence of a nonpreferential nitrogen source (amino acids, choline, etc.), the activation of paPpx is at transcriptional level since the expression of the $p p x$ gene is under the control of the global regulator NtrC [8]. On the other hand, with a good availability of nitrogen in the environment, $\mathrm{NH}_{4}{ }^{+}$directly stimulates the enzymatic activity and the bacteria obtain energy to start their growth.

Taking all these reports together, it was evident that polyP levels are involved in the global energetic state of the cell. Thus, we wondered if $p a P p x$ could have a second function, such as the synthesis of ATP by transferring $\mathrm{P}_{\mathrm{i}}$ from polyP to a molecule of ADP. Confirming what we previously hypothesized, we found that $p a \mathrm{Ppx}$ is also a polyP:ADP phosphotransferase. As the phosphatase activity, the phosphotransferase activity is located in the $\mathrm{N}$-terminal domain and depends on $\mathrm{Mg}^{2+}$; however, it is insensitive to the addition of $\mathrm{K}^{+}$or $\mathrm{NH}_{4}{ }^{+}$, suggesting that the catalytic mechanism is somehow different, probably acting nonprocessively.

Additionally, we performed in silico assays to complement our experimental data. We modeled the full-length $p a \mathrm{Ppx}$ in a closed conformation and the $\mathrm{N}-p a \mathrm{Ppx}$ in an open conformation.

In $E$. coli, the active site was proposed to lay in a cleft between subdomains I and II [13] and a glycine-rich phosphate-binding loop more likely stabilizes the transition state during catalysis [14]. paPpx has full conservation of the proposed active site residues from ecPpx that would be formed by Glu ${ }^{156}$, Asp ${ }^{149}, \mathrm{Gly}^{151}, \mathrm{Ser}^{154}$, and Glu ${ }^{126}$ and the glycine-rich loop consisting of residues Gly $^{141}-$ Ser $^{154}$. 
The conserved $\mathrm{Glu}^{126}$ is proposed as the residue which activates a water molecule for the nucleophilic attack to the phosphodiester bond. The solved structures of ecPpx lack the $\mathrm{Mg}^{2+}$ bound to the enzyme. The putative $\mathrm{Mg}^{2+}$ binding site was suggested by comparison with the binding of $a a \mathrm{Ppx}$ to a $\mathrm{Ca}^{2+}$ atom [17]. By analogy to the description of $e c \mathrm{Ppx}$, the acidic residues Asp ${ }^{149}$ and $\mathrm{Glu}^{156}$ are predicted to contribute to the coordination sphere of $\mathrm{Mg}^{2+}$ in $p a \mathrm{Ppx}$ [14]. We confirmed the participation of $\mathrm{Glu}^{126}, \mathrm{Asp}^{149}, \mathrm{Ser}^{154}$, $\mathrm{Gly}^{151}$, and $\mathrm{Glu}^{156}$ residues in the active site by nonconservative site-directed mutagenesis in the full-length $p a \mathrm{Ppx}$. The phosphotransferase activity of $p a \mathrm{Ppx}$ was also measured in the mutated variants of $p a \mathrm{Ppx}$ and no ATP production was detected. This result indicates that the active site of $p a \mathrm{Ppx}$ is the same for both activities: the phosphotransferase and the hydrolase.

It has been reported that $e c \mathrm{Ppx}$ and $a a \mathrm{Ppx}$ also presented pppGpp activity [17, 26, 43, 44], suggesting that the active site would have enough space to bind a nucleotide. Other authors $[13,14,26]$ have debated whether there are two different active sites or a common one. Considering the work presented by Kristensen and collaborators [26] who have reported the structure of aaPpx (in presence and absence of the alarmone ppGpp), it is clear that there is a single active site for hydrolysis of both polyP and pppGpp. As it was suggested by [14], ecPpx must undergo a conformational change from the closed to the open state to allow the entry of the nucleotide pppGpp. A phosphotransferase activity was never described for exopolyphosphatases or PPX/GPPA phosphatases; this work is the first reporting ATP production in a Ppx. Our results suggest that in $p a P p x$ the same active site is responsible for this activity, and we think that the transition from the closed to the open conformation occurs also in $p a \mathrm{Ppx}$ to allow the entry of ADP. The pppGpp molecule in the active site is occupying the space that would occupy both polyP and ADP (Figure 3(b)). Considering that we propose that the active site for phosphotransferase and phosphatase activities is the same, we would expect that other Ppx/GPPA phosphatases also have the ability to synthesize ATP. A major aspect that remains to be characterized in the $p a \mathrm{Ppx}$ is the binding site of the polyP chain. This site is not well defined because so far there is no crystal structure of a Ppx bound to the substrate polyP. The polyP binding site has been suggested in E. coli by two different approaches. Alvarado and collaborators [13] have described a possible binding area based on several sulfate ions present in the crystal, assuming that sulfates may mimic phosphates. On the other hand, Rangarajan and collaborators [14] suggested the presence of a channel of highly positive electrostatic potential for polyP binding at the dimerization interface. Both approaches are consistent in the suggested areas for polyP binding to ecPpx. These areas include the residues $\mathrm{Arg}^{165}, \operatorname{Arg}^{166}, \operatorname{Arg}^{189}$, and $\mathrm{Lys}^{197}$ corresponding to a monomer and $\mathrm{His}^{378}$, $\mathrm{His}^{384}$, $\mathrm{Arg}^{383}, \mathrm{Arg}^{413}$, Lys $^{414}$, and Lys ${ }^{488}$ corresponding to the other monomer. Within these, it was found that Arg ${ }^{166}$, Lys ${ }^{197}$, $\mathrm{His}^{378}$, and $\mathrm{Arg}^{413}$ triads are linked to sulfate ions in a crystal. It is very striking that in $p a \mathrm{Ppx}$ only half of these residues are conserved. Thus, the channel formed after dimerization had a less positive electrostatic potential (Figure 3). Residues in this region of $p a \mathrm{Ppx}$ are $\mathrm{Leu}^{171}, \mathrm{Gln}^{172}, \mathrm{Gln}^{195}, \mathrm{Glu}^{203}, \mathrm{His}^{383}$, $\mathrm{His}^{389}, \mathrm{Lys}^{388}, \mathrm{Arg}^{418}, \mathrm{Arg}^{419}$, and $\mathrm{Gln}^{491}$. This leads us to believe that while there is a channel, the potential is much less positive and, therefore, there must be differences in the binding of both enzymes with polyP. One of the possible roles of $\mathrm{K}^{+}$in the activity of paPpx may be the stabilization of the negative charges of polyP. This ion would also be involved in the constant attachment and detachment of the polymer during processive catalysis. If so, the interaction between the polyP and the enzyme in ecPpx would be stronger than in $p a \mathrm{Ppx}$ and, thus, greater amounts of $\mathrm{K}^{+}$would be required to detach the polyP in each catalysis cycle. We believe that

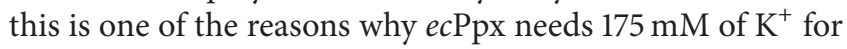
maximal activity whereas paPpx needs only $80 \mathrm{mM}$.

\section{Concluding Remarks}

In the present survey we show that, similarly to $e c \mathrm{Ppx}$, the catalytic activity of $p a \mathrm{Ppx}$ is found in the $\mathrm{N}$-terminal region formed by subdomains I and II. This N-terminal domain is unable to distinguish the long polyP chain of beyond 15 residues in length. As occurs with ecPpx, the activity of $p a \mathrm{Ppx}$ depends on $\mathrm{Mg}^{2+}$ and is activated by $\mathrm{K}^{+}$. In addition, we found and described new and original properties of $p a \mathrm{Ppx}$, including that the polypeptide connecting the $\alpha$-helices from subdomains II and III is necessary for the catalytic activity and $\mathrm{NH}_{4}{ }^{+}$is an activator of the enzyme and may work at lower concentrations than $\mathrm{K}^{+}$. Finally, we demonstrate that $p a \mathrm{Ppx}$ has also a phosphotransferase activity capable of producing ATP. Surprisingly, this activity is dependent on $\mathrm{Mg}^{2+}$ but is not activated by $\mathrm{NH}_{4}^{+}$or $\mathrm{K}^{+}$, suggesting that, in spite of the fact that the active site is the same, the catalytic mechanism is slightly different.

The regulation of the degradation of polyP is complex and dual, since it involves regulation at transcriptional and biochemical levels. Thus, bacteria have mechanisms which ensure that $p a \mathrm{Ppx}$ is active in various physiological situations such as (i) under nitrogen limitation, where $p p x$ is activated by $\mathrm{NtrC}$, mediated by a $\sigma^{54}$-dependent promoter [8]; (ii) under $\mathrm{P}_{\mathrm{i}}$ deficiency mediated by $\mathrm{PhoB}$ by a $\sigma^{70}$-dependent promoter; (iii) in the presence of preferential nitrogen source $\left(\mathrm{NH}_{4}{ }^{+}\right)$, where the transcription of $p p x$ is inhibited but the existing enzyme can be directly activated; and (iv) under hyperosmolarity, where $p a \mathrm{Ppx}$ is rapidly activated by $\mathrm{K}^{+}$, the most prevalent cation in the cytoplasm. This enzyme with its two functions can release $P_{i}$ for a direct synthesis of ATP or meet the nutritional needs where $P_{i}$ is necessary either to generate more energy or to initiate metabolic processes.

Together, the foregoing data and observations point out that $p a \mathrm{Ppx}$ is an enzyme of remarkable relevance due to its implication in polyP metabolism and, consequently, in virulence and pathogenesis of $P$. aeruginosa. Despite the fact that several specific aspects related to the paPpx enzyme, such as the detection of the specific binding site of the polyP chain, remain to be characterized, our present work contributes to the understanding of activity of the enzyme and of 
some physiological aspects of $P$. aeruginosa as opportunistic pathogen.

Abbreviations
$\begin{array}{ll}\text { polyP: } & \text { Polyphosphate } \\ \mathrm{P}_{\mathrm{i}}: & \text { Inorganic phosphate } \\ \text { pppGpp: } & \text { Guanosine pentaphosphate } \\ \mathrm{MD}: & \text { Molecular dynamics } \\ \mathrm{NPT}: & \text { Isothermal-isobaric (NPT) ensemble } \\ \text { vdW: } & \text { van der Waals. }\end{array}$

\section{Disclosure}

Paola R. Beassoni and Angela T. Lisa are Career Members of the Consejo Nacional de Investigaciones Científicas y Técnicas (CONICET).

\section{Conflict of Interests}

The authors declare that there is no conflict of interests regarding the publication of this paper.

\section{Authors' Contribution}

Paola R. Beassoni and Cristhian Boetsch carried out the in silico studies. Lucas A. Gallarato carried out the molecular and biochemical studies. Mónica N. Garrido discussed and analyzed part of the data. Angela T. Lisa designed part of the research and discussed the results. Paola R. Beassoni designed part of the research, analyzed and discussed the data, and wrote the paper.

\section{Acknowledgments}

Lucas A. Gallarato and Cristhian Boetsch would like to acknowledge fellowship support from CONICET. Paola R. Beassoni thanks Dr. Danilo-Gonzalez Nilo from Centro de Biología Integrativa y Bioinformática de la Universidad Andres Bello, Chile, for access to computational facility. The authors' special gratitude is due to Dr. Carlos E. Domenech for his expert help in this work and fruitful discussion. This work was supported by grants from SECYT-UNRC, MinCyTCba, and CONICET.

\section{References}

[1] I. Kulaev and T. Kulakovskaya, "Polyphosphate and phosphate pump," Annual Review of Microbiology, vol. 54, pp. 709-734, 2000.

[2] M. H. Rashid, K. Rumbaugh, L. Passador et al., "Polyphosphate kinase is essential for biofilm development, quorum sensing, and virulence of Pseudomonas aeruginosa," Proceedings of the National Academy of Sciences of the United States of America, vol. 97, no. 17, pp. 9636-9641, 2000.

[3] M. H. Rashid and A. Kornberg, "Inorganic polyphosphate is needed for swimming, swarming, and twitching motilities of Pseudomonas aeruginosa," Proceedings of the National Academy of Sciences of the United States of America, vol. 97, no. 9, pp. 4885-4890, 2000.

[4] M. H. Rashid, N. N. Rao, and A. Kornberg, "Inorganic polyphosphate is required for motility of bacterial pathogens," Journal of Bacteriology, vol. 182, no. 1, pp. 225-227, 2000.

[5] N. N. Rao, M. R. Gómez-García, and A. Kornberg, "Inorganic polyphosphate: essential for growth and survival," Annual Review of Biochemistry, vol. 78, no. 1, pp. 605-647, 2009.

[6] D. Dacheux, O. Epaulard, A. De Groot et al., "Activation of the Pseudomonas aeruginosa type III secretion system requires an intact pyruvate dehydrogenase ace AB operon," Infection and Immunity, vol. 70, no. 7, pp. 3973-3977, 2002.

[7] T. L. Yahr, A. J. Vallis, M. K. Hancock, J. T. Barbieri, and D. W. Frank, "ExoY, an adenylate cyclase secreted by the Pseudomonas aeruginosa type III system," Proceedings of the National Academy of Sciences of the United States of America, vol. 95, no. 23, pp. 13899-13904, 1998.

[8] L. A. Gallarato, D. G. Sánchez, L. Olvera et al., "Exopolyphosphatase of Pseudomonas aeruginosa is essential for the production of virulence factors, and its expression is controlled by $\mathrm{NtrC}$ and PhoB acting at two interspaced promoters," Microbiology, vol. 160, no. 2, pp. 406-417, 2014.

[9] D. Ault-Riché, C. D. Fraley, C.-M. Tzeng, and A. Kornberg, "Novel assay reveals multiple pathways regulating stressinduced accumulations of inorganic polyphosphate in Escherichia coli," Journal of Bacteriology, vol. 180, no. 7, pp. 1841-1847, 1998.

[10] H.-Y. Kim, D. Schlictman, S. Shankar, Z. Xie, A. M. Chakrabarty, and A. Kornberg, "Alginate, inorganic polyphosphate, GTP and ppGpp synthesis co-regulated in Pseudomonas aeruginosa: implications for stationary phase survival and synthesis of RNA/DNA precursors," Molecular Microbiology, vol. 27, no. 4, pp. 717-725, 1998.

[11] T. Miyake, T. Shiba, A. Kameda et al., "The gene for an exopolyphosphatase of Pseudomonas aeruginosa," DNA Research, vol. 6, no. 2, pp. 103-108, 1999.

[12] A. Zago, S. Chugani, and A. M. Chakrabarty, "Cloning and characterization of polyphosphate kinase and exopolyphosphatase genes from Pseudomonas aeruginosa 8830," Journal of Bacteriology, vol. 182, pp. 6687-6693, 1999.

[13] J. Alvarado, A. Ghosh, T. Janovitz, A. Jauregui, M. S. Hasson, and D. A. Sanders, "Origin of exopolyphosphatase processivity: fusion of an ASKHA phosphotransferase and a cyclic nucleotide phosphodiesterase homolog," Structure, vol. 14, no. 8, pp. 12631272,2006

[14] E. S. Rangarajan, G. Nadeau, Y. Li et al., "The structure of the exopolyphosphatase (PPX) from Escherichia coli O157:H7 suggests a binding mode for long polyphosphate chains," Journal of Molecular Biology, vol. 359, no. 5, pp. 1249-1260, 2006.

[15] D. G. Bolesch and J. D. Keasling, "Polyphosphate binding and chain length recognition of Escherichia coli exopolyphosphatase," The Journal of Biological Chemistry, vol. 275, no. 43, pp. 33814-33819, 2000.

[16] I. S. Kulaev, V. M. Vagabov, and T. V. Kulakovskaya, The Biochemistry of Inorganic Polyphosphates, John Wiley \& Sons, Chichester, UK, 2004.

[17] O. Kristensen, M. Laurberg, A. Liljas, J. S. Kastrup, and M. Gajhede, "Structural characterization of the stringent response related exopolyphosphatase/guanosine pentaphosphate phosphohydrolase protein family," Biochemistry, vol. 43 , no. 28 , pp. 8894-8900, 2004. 
[18] L. H. Otero, P. R. Beassoni, A. T. Lisa, and C. E. Domenech, "Transition from octahedral to tetrahedral geometry causes the activation or inhibition by $\mathrm{Zn}^{2+}$ of Pseudomonas aeruginosa phosphorylcholine phosphatase," BioMetals, vol. 23, no. 2, pp. 307-314, 2010.

[19] S. D. Katewa and S. S. Katyare, "A simplified method for inorganic phosphate determination and its application for phosphate analysis in enzyme assays," Analytical Biochemistry, vol. 323, no. 2, pp. 180-187, 2003.

[20] E. Gasteiger, C. Hoogland, A. Gattiker et al., "Protein identification and analysis tools on the ExPASy server," in The Proteomics Protocols Handbook, pp. 571-607, Humana Press Inc, Clifton, NJ, USA, 2005.

[21] R. Abagyan, M. Totrov, and D. Kuznetsov, "ICM-a new method for protein modeling and design: applications to docking and structure prediction from the distorted native conformation," Journal of Computational Chemistry, vol. 15, no. 5, pp. 488-506, 1994.

[22] M. Wiederstein and M. J. Sippl, "ProSA-web: interactive web service for the recognition of errors in three-dimensional structures of proteins," Nucleic Acids Research, vol. 35, no. 2, pp. W407-W410, 2007.

[23] F. Melo and E. Feytmans, "Assessing protein structures with a non-local atomic interaction energy," Journal of Molecular Biology, vol. 277, no. 5, pp. 1141-1152, 1998.

[24] R. A. Laskowski, M. W. MacArthur, D. S. Moss, and J. M. Thornton, "PROCHECK: a program to check the stereochemical quality of protein structures," Journal of Applied Crystallography, vol. 26, no. 2, pp. 283-291, 1993.

[25] W. Humphrey, A. Dalke, and K. Schulten, "VMD: visual molecular dynamics," Journal of Molecular Graphics, vol. 14, no. 1, pp. 33-38, 1996.

[26] O. Kristensen, B. Ross, and M. Gajhede, "Structure of the PPX/GPPA phosphatase from Aquifex aeolicusin complex with the alarmone ppGpp," Journal of Molecular Biology, vol. 375, no. 5, pp. 1469-1476, 2008.

[27] L. A. Kelley and M. J. E. Sternberg, "Protein structure prediction on the Web: a case study using the Phyre server," Nature Protocols, vol. 4, no. 3, pp. 363-371, 2009.

[28] J. C. Phillips, R. Braun, W. Wang et al., "Scalable molecular dynamics with NAMD," Journal of Computational Chemistry, vol. 26, no. 16, pp. 1781-1802, 2005.

[29] U. Essmann, L. Perera, M. L. Berkowitz, T. Darden, H. Lee, and L. G. Pedersen, "A smooth particle mesh Ewald method," The Journal of Chemical Physics, vol. 103, no. 19, pp. 8577-8593, 1995.

[30] G. P. Poornam, A. Matsumoto, H. Ishida, and S. Hayward, "A method for the analysis of domain movements in large biomolecular complexes," Proteins: Structure, Function and Bioinformatics, vol. 76, no. 1, pp. 201-212, 2009.

[31] N. A. Baker, D. Sept, S. Joseph, M. J. Holst, and J. A. McCammon, "Electrostatics of nanosystems: application to microtubules and the ribosome," Proceedings of the National Academy of Sciences of the United States of America, vol. 98, no. 18, pp. 10037-10041, 2001.

[32] T. J. Dolinsky, P. Czodrowski, H. Li et al., "PDB2PQR: expanding and upgrading automated preparation of biomolecular structures for molecular simulations," Nucleic Acids Research, vol. 35, no. 2, pp. W522-W525, 2007.

[33] H. Li, A. D. Robertson, and J. H. Jensen, "Very fast empirical prediction and rationalization of protein $\mathrm{pK}_{a}$ values," Proteins: Structure, Function and Genetics, vol. 61, no. 4, pp. 704-721, 2005.
[34] P. R. Beassoni, L. H. Otero, C. Boetsch, C. E. Domenech, F. D. González-Nilo, and Á. T. Lisa, "Site-directed mutations and kinetic studies show key residues involved in alkylammonium interactions and reveal two sites for phosphorylcholine in Pseudomonas aeruginosa phosphorylcholine phosphatase," Biochimica et Biophysica Acta-Proteins and Proteomics, vol. 1814, no. 7, pp. 858-863, 2011.

[35] R. D. Finn, J. Clements, and S. R. Eddy, "HMMER web server: interactive sequence similarity searching," Nucleic Acids Research, vol. 39, no. 2, pp. W29-W37, 2011.

[36] F. Sievers and D. G. Higgins, "Clustal omega, accurate alignment of very large numbers of sequences," in Multiple Sequence Alignment Methods, pp. 105-116, Humana Press, 2014.

[37] M. Akiyama, E. Crooke, and A. Kornberg, "An exopolyphosphatase of Escherichia coli. the enzyme and its $p p x$ gene in a polyphosphate operon," The Journal of Biological Chemistry, vol. 268, no. 1, pp. 633-639, 1993.

[38] G. E. Crooks, G. Hon, J.-M. Chandonia, and S. E. Brenner, "WebLogo: a sequence logo generator," Genome Research, vol. 14, no. 6, pp. 1188-1190, 2004.

[39] S. T. Cardona, F. P. Chávez, and C. A. Jerez, "The exopolyphosphatase gene from Sulfolobus solfataricus: characterization of the first gene found to be involved in polyphosphate metabolism in Archaea," Applied and Environmental Microbiology, vol. 68, no. 10, pp. 4812-4819, 2002.

[40] N. A. Andreeva, T. V. Kulakovskaya, and I. S. Kulaev, "Two exopolyphosphatases of the cytosol of the yeast S. cerevisiae: comparative characteristics," Biochemistry, vol. 66, no. 2, pp. 147-153, 2001.

[41] T. Dudev and C. Lim, "Metal selectivity in metalloproteins: $\mathrm{Zn}^{2+}$ vs $\mathrm{Mg}^{2+}$, Journal of Physical Chemistry B, vol. 105, no. 19, pp. 4446-4452, 2001.

[42] L. N. Csonka, "Physiological and genetic responses of bacteria to osmotic stress," Microbiological Reviews, vol. 53, no. 1, pp. 121147, 1989.

[43] J. D. Keasling, L. Bertsch, and A. Kornberg, "Guanosine pentaphosphate phosphohydrolase of Escherichia coli is a long- chain exopolyphosphatase," Proceedings of the National Academy of Sciences of the United States of America, vol. 90, no. 15, pp. 70297033, 1993.

[44] A. Kuroda, H. Murphy, M. Cashel, and A. Kornberg, "Guanosine tetra- and pentaphosphate promote accumulation of inorganic polyphosphate in Escherichia coli," Journal of Biological Chemistry, vol. 272, no. 34, pp. 21240-21243, 1997. 

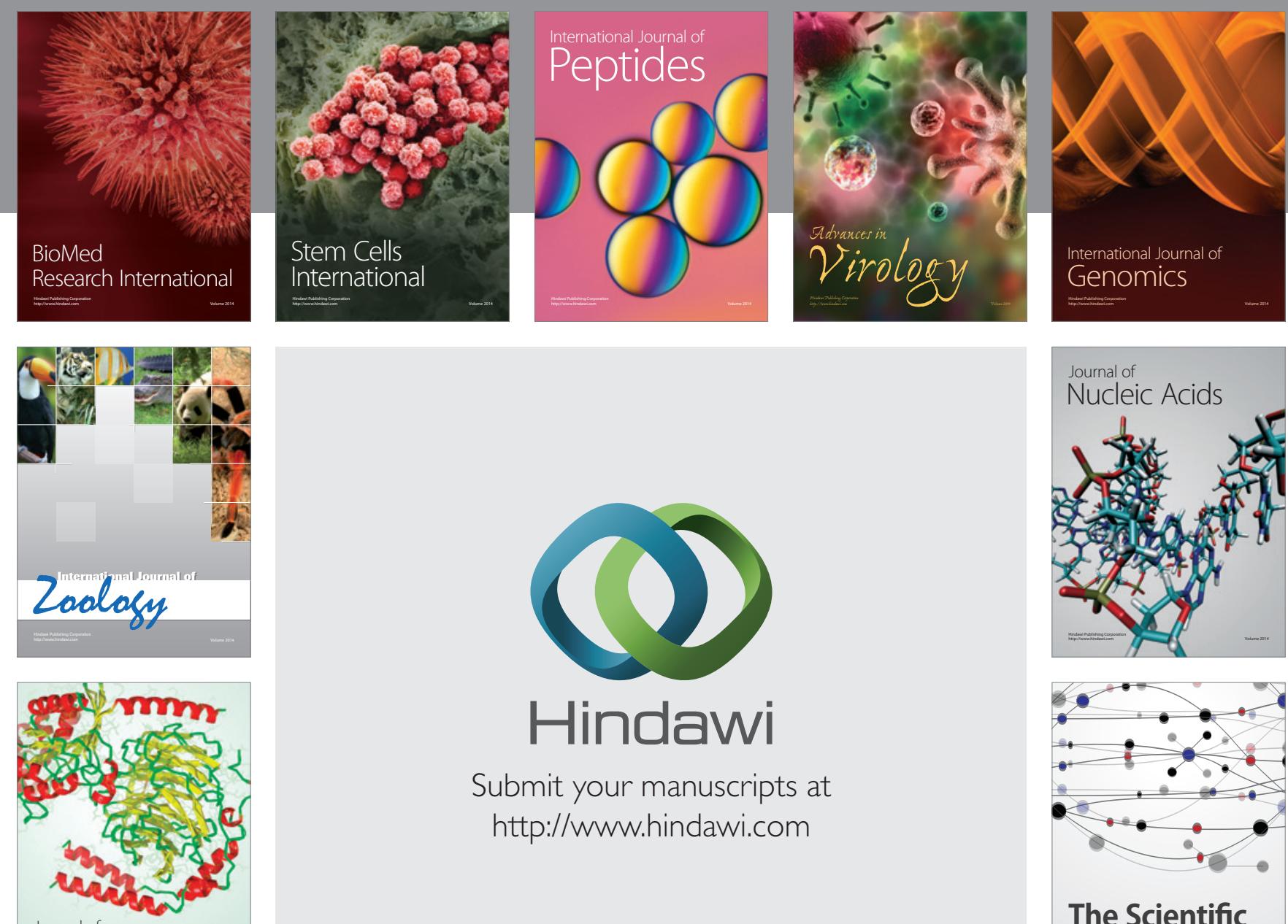

Submit your manuscripts at

http://www.hindawi.com

Journal of
Signal Transduction
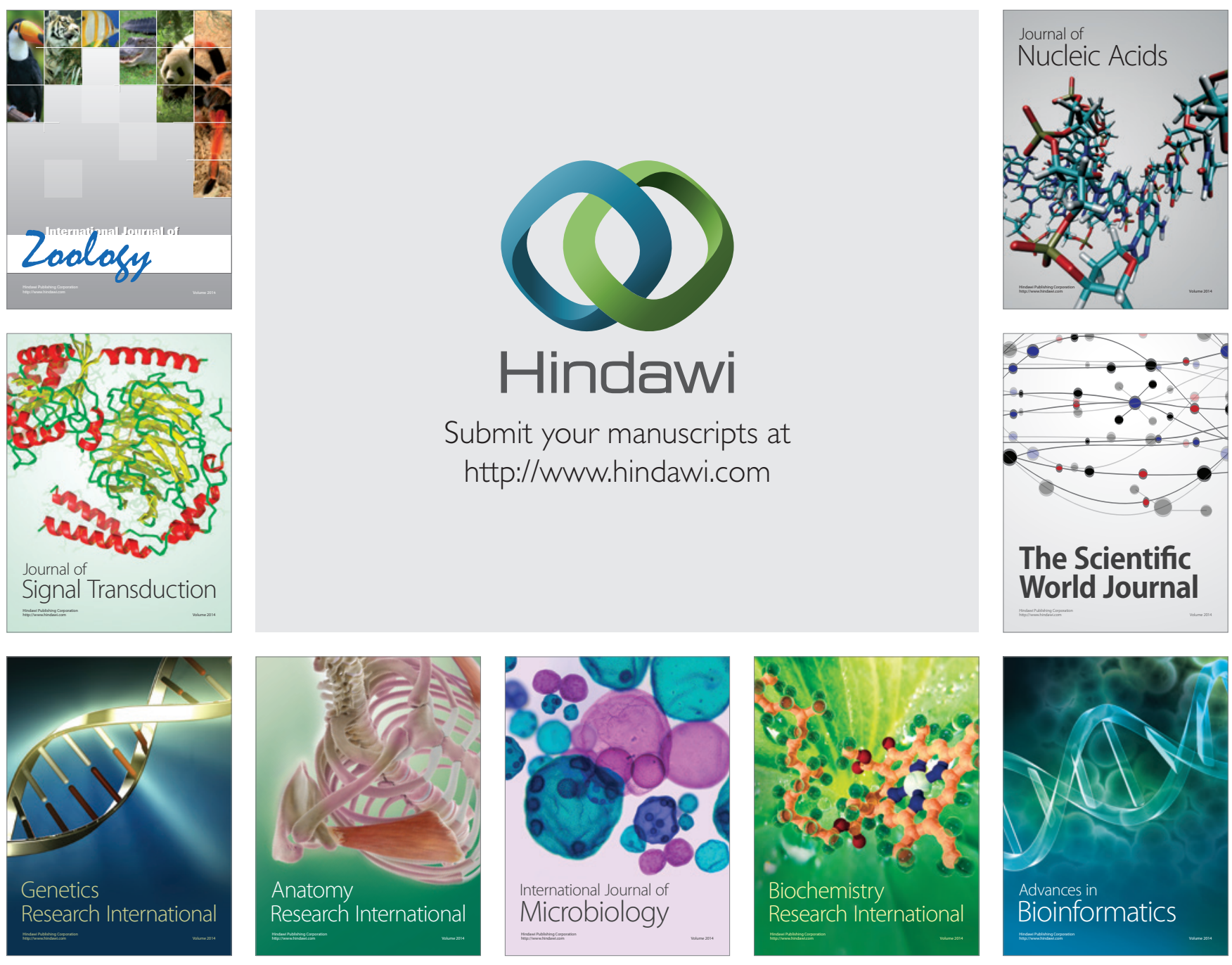

The Scientific World Journal
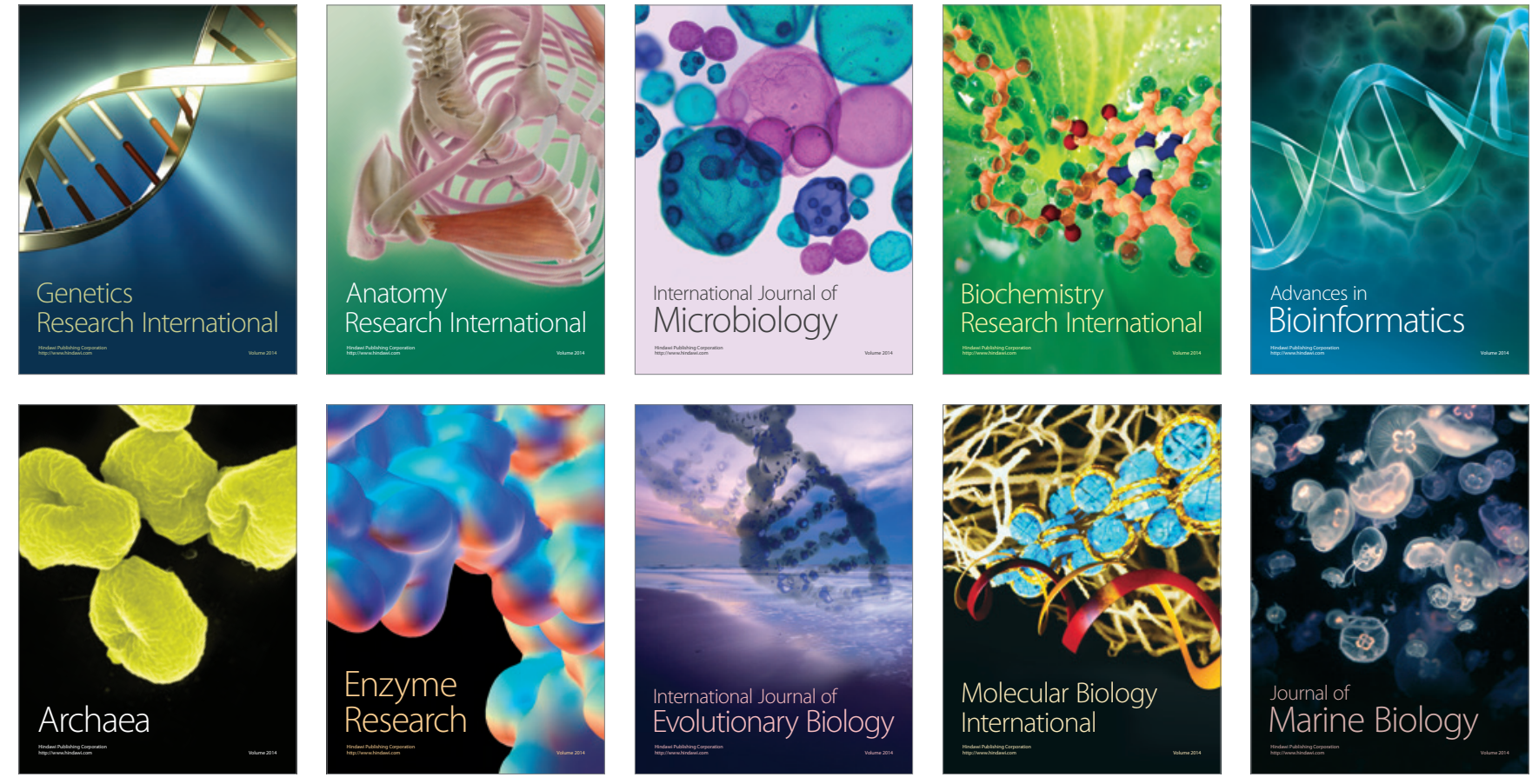